\title{
40006
}

WORLD B A N K W ORK I N G PAPER N O. $\begin{array}{llllllllll} & 0 & 2\end{array}$

\section{South-South Migration and Remittances}

Dilip Ratha

William Shaw 

\begin{tabular}{llllllllllllllllllllll} 
W O R L D & B A N N K W O R K I N G P A P E R N & O & I & 0 & 2 \\
\hline
\end{tabular}

\section{South-South Migration and Remittances}

Dilip Ratha and William Shaw

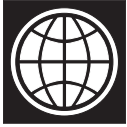

THE WORLD BANK

Washington, D.C. 
Copyright $@ 2007$

The International Bank for Reconstruction and Development/The World Bank

1818 H Street, N.W.

Washington, D.C. 20433, U.S.A.

All rights reserved

Manufactured in the United States of America

First Printing: April 2007

8 printed on recycled paper

1234510090807

World Bank Working Papers are published to communicate the results of the Bank's work to the development community with the least possible delay. The manuscript of this paper therefore has not been prepared in accordance with the procedures appropriate to formally-edited texts. Some sources cited in this paper may be informal documents that are not readily available.

The findings, interpretations, and conclusions expressed herein are those of the author(s) and do not necessarily reflect the views of the International Bank for Reconstruction and Development/The World Bank and its affiliated organizations, or those of the Executive Directors of The World Bank or the governments they represent.

The World Bank does not guarantee the accuracy of the data included in this work. The boundaries, colors, denominations, and other information shown on any map in this work do not imply any judgment on the part of The World Bank of the legal status of any territory or the endorsement or acceptance of such boundaries.

The material in this publication is copyrighted. Copying and/or transmitting portions or all of this work without permission may be a violation of applicable law. The International Bank for Reconstruction and Development/The World Bank encourages dissemination of its work and will normally grant permission promptly to reproduce portions of the work.

For permission to photocopy or reprint any part of this work, please send a request with complete information to the Copyright Clearance Center, Inc., 222 Rosewood Drive, Danvers, MA 01923, USA, Tel: 978-750-8400, Fax: 978-750-4470, www.copyright.com.

All other queries on rights and licenses, including subsidiary rights, should be addressed to the Office of the Publisher, The World Bank, 1818 H Street NW, Washington, DC 20433, USA, Fax: 202-522-2422, email: pubrights@worldbank.org.

ISBN-10: 0-8213-7072-3

ISBN-13: 978-0-8213-7072-8

eISBN: $978-0-8213-7073-5$

ISSN: $1726-5878$

DOI: $10.1596 / 978-0-8213-7072-8$

Ratha Dilip is a Senior Economist in the Development Prospects Group of the World Bank. William Shaw is a Consultant to the same unit.

\section{Library of Congress Cataloging-in-Publication Data}

Ratha, Dilip.

South-south migration and remittances/Dilip Ratha and William Shaw.

p. cm. -- (World Bank working paper ; no. 102)

Includes bibliographical references.

ISBN-13: 978-0-8213-7072-8

ISBN-10: 0-8213-7072-3

ISBN-13: 978-0-8213-7073-5 (electronic)

1. Emigrant remittances. I. Shaw, William, 1953- II. World Bank. Development Prospects

Group. Migration and Remittances Team. III. Title.

HG3891.R37 2007

330.9172'4--dc22

2007008821 


\section{Contents}

Abstract

Foreward vii

Acknowledgments $\quad$ ix

Introduction and Main Findings $\quad 1$

1. The Extent of South-South Migration 3

2. South-South Remittances 11

South-South Remittance Costs 13

3. Determinants of South-South Migration 15

$\begin{array}{ll}\text { Proximity } & 15\end{array}$

$\begin{array}{ll}\text { Networks } & 16\end{array}$

$\begin{array}{ll}\text { Income } & 17\end{array}$

$\begin{array}{ll}\text { Seasonal Migration } & 19\end{array}$

$\begin{array}{ll}\text { Transit } & 19\end{array}$

$\begin{array}{ll}\text { Petty Trade } & 20\end{array}$

$\begin{array}{ll}\text { Conflict and Disaster } & 20\end{array}$

4. Socioeconomic Dimensions of South-South Migration 23

Wages 23

Irregular Migration $\quad 25$

$\begin{array}{ll}\text { Health } & 27\end{array}$

$\begin{array}{ll}\text { Gender } & 28\end{array}$

Trafficking in Persons $\quad 29$

Instability $\quad 30$

5. Conclusion 33

Appendixes $\quad 35$

A. Bilateral Migration Data $\quad 37$

B. Estimating Bilateral Remittances 43

$\begin{array}{ll}\text { C. Remittance Costs } & 47\end{array}$

$\begin{array}{ll}\text { References } & 49\end{array}$

About the Authors $\quad 55$ 


\section{LIST OF TABLES}

1. Global Migrant Stocks 5

2. Intra- and Inter-regional Migration 6

3. Estimates of South-South Remittances Using Different Methods 12

4. Migration Patterns by Income Classification 18

5. Refugees and Asylum Seekers 21

6. Change in Wages in Destination Countries from Increased South-North and South-South Migration $\quad 24$

A1. DECPG Updates of University of Sussex Data 39

C1. The Costs of Remitting \$200 in Selected Corridors 48

\section{LIST OF FIGURES}

1. Migration Has Been Rising in the South, But at a Slower Pace than in the North

2. South-South Migration is Greater than South-North Migration in Three Regions

3. Top 20 Migration Corridors Excluding the Former Soviet Union

4. Top 20 Migration Corridors in the Former Soviet Union 8

5. South-South Remittance Fees Tend to be Higher than North-South Remittance Fees

6. South-South Migration Occurs Primarily among

Neighboring Countries

\section{Box}

1. The Role of Regional and Bilateral Agreements in Regulating South-South Migration 


\section{Abstract}

Tn this paper, we report preliminary results from an ongoing effort to improve data on

Lilateral migration stocks, and set out some working hypotheses on the determinants and socioeconomic implications of South-South migration drawing on a survey of the literature. We estimate that 74 million, or nearly half, of the migrants from developing countries reside in other developing countries. In other words, South-South migration is nearly as large as South-North migration. Almost 80 percent of South-South migration is estimated to take place between countries with contiguous borders, and most appears to occur between countries with relatively small differences in income. Estimates of South-South remittances range from 10 to 29 percent of developing countries' remittance receipts in 2005 , depending on the allocation rule chosen to estimate bilateral flows. The impact of South-South migration on the income of migrants and natives is smaller than for SouthNorth migration. However, even small increases in income can have substantial welfare implications for the poor, and cross-migration can improve the match between skills and requirements in the countries involved, thus raising efficiency and welfare. The costs of South-South remittances (where such remittances are permitted) are even higher than those of North-South remittances, because of lack of competition in the remittance market, a lack of financial development in general, and high foreign exchange commissions at both ends of the transaction. These findings suggest that policymakers should pay attention to the complex challenges that developing countries face not only as the countries of origin of migrants, but also as destinations. Designing appropriate policies, however, will require considerable efforts to improve data, and careful analysis of the socioeconomic impact of migration on wages, income distribution, gender, health, and migrants' rights.

The data sets on bilateral migration stocks and bilateral remittance flows worldwide are posted at www.worldbank.org/prospects/migrationandremittances. 



\section{Foreword}

Tnternational migration is a complex and often controversial issue. The challenge for

$I_{\text {policymakers is to achieve the potential economic benefits of migration while managing }}$ the associated social and political risks.

This paper shows that, while the policy debate and research on migration has focused on South-North flows, South-South migration is almost as prevalent: nearly half of the migrants from the South may be living in other developing countries; and developing countries face policy challenges not only as sending countries, but also as destination countries.

Developing appropriate migration policies for countries in the South will require improving the data and careful analysis of the socioeconomic implications for wages, income distribution, health, irregular migration, and migrants' rights. The paper outlines efforts to put together a database on bilateral migration stock and bilateral remittance flows for 212 countries based on national censuses and other data sources. It provides a comprehensive survey of the literature on this topic and sets out some working hypotheses on the determinants and socioeconomic implications of South-South migration.

The paper represents a continuing effort of the Development Prospects Group of the World Bank in MAPing (monitoring, analysis and projection) of migration and remittances at the global, regional and country levels. It builds on the Global Economic Prospects 2006: Economic Implications of Remittances and Migration, and is an integral part of a broader work program on migration, remittances, and development at the World Bank.

Uri Dadush

Director

Development Prospects Group

The World Bank 



\section{Acknowledgments}

This paper was prepared by the Migration and Remittances Team of the Development

1 Prospects Group of the World Bank. The lead authors of this paper are Dilip Ratha and William Shaw, with direction by Uri Dadush. Constructive comments and advice from Andrew Burns, Robert E. B. Lucas and Hania Zlotnik are gratefully acknowledged. Significant contributions were received from: Sanket Mohapatra on the estimation of South-South migration and remittances and the preparation of the trends section; Irena Omelaniuk on the discussion of policies; and Dominique van der Mensbrugghe on modeling of gains. Christopher Parsons collaborated with the Team to update a database of bilateral migration stocks provided by the University of Sussex. Zhimei Xu provided excellent research assistance. Christina Savescu contributed to the review of the literature on South-South migration and the collection of data on remittance costs. Thanks to Maria Amparo Gamboa, Damian Ondo, and Victor Sulla for assistance in collecting information on remittance costs.

An earlier version of this paper was presented at a side-event during the High-Level Dialogue on Migration and Development, United Nations, New York, September 14, 2006. This version reflects comments received from the participants at this event. The views expressed in this paper represent those of the authors, not necessarily of the World Bank. 



\section{Introduction and Main Findings}

$\mathrm{B}$ $y$ a rough estimate, in 2005 two of every five migrants on the globe-some 78 million out of 191 million migrants - were residing in a developing country. Most of these migrants are likely to have come from other developing countries. The extent and issues surrounding migration between developing countries, however, remain poorly understood, largely because data on migration in developing countries are incomplete and unreliable. ${ }^{1}$

In this paper, we report preliminary results from an ongoing effort to improve data on bilateral migration stocks, and set out some working hypotheses on the determinants and socioeconomic implications of South-South migration drawing on a survey of the literature. ${ }^{2}$ Using these new estimates of bilateral migration data and some plausible assumptions about migrants' remittance behavior, we also try to estimate South-South remittance flows. In addition, we report preliminary estimates of the welfare impacts of South-South migration using the methodology employed in World Bank (2005) for evaluating the impacts of South-North migration. Given the preliminary nature of this work, further research is planned to refine the estimates of migration stocks and remittance flows, and to evaluate the welfare impact of migration on developing countries. Nevertheless, we have sufficient information to suggest some broad conclusions about the nature of South-South

1. To quote from Hatton and Williamson (2002), "South-South migration is not new. It is just ignored by economists."

2. In this paper, the South is defined to comprise developing countries as defined by the World Bank. This definition is narrower than those used by the United Nations and other organizations. For details, see Appendix A. 
migration, which will be further explored in future work. The following preliminary results emerge from these efforts:

Our current estimates indicate that 74 million, or nearly half, of the migrants from developing countries reside in other developing countries. However, we believe this estimate is likely to be low, as the official data tend to undercount irregular migrants. Irregular migration is probably even more common in South-South than South-North migration because of tight restrictions on immigration in many developing countries, coupled with limited enforcement, the high cost of travel documents, and unclear immigration rules in the South.

Almost 80 percent of South-South migration is estimated to take place between countries with contiguous borders, and most appears to occur between countries with relatively small differences in income. In contrast, while proximity can be important in shaping South-North migration, large income differences encourage migration over greater distances.

Estimates of South-South remittances range from 9 to 30 percent of developing countries' remittance receipts, or between $\$ 18$ billion and $\$ 55$ billion in 2005, depending on the allocation rule chosen to estimate bilateral flows - the estimate is high when the allocation rule is based on migrant stocks, but low when it is based on migrant incomes (which tend to be higher in the North). These estimates are based on officially recorded remittances of $\$ 188$ billion to the South in 2005-the amounts would be higher if flows through informal channels were taken into account.

The impact of South-South migration on the income of migrants and natives is smaller than for South-North migration. However, even small increases in income can have substantial welfare implications for the poor, and cross-migration can improve the match between skills and requirements in the countries involved, thus raising efficiency and welfare.

The costs of South-South remittances (where such remittances are permitted) are even higher than those of North-South remittances, because of lack of competition in the remittance market, a lack of financial development in general, and high foreign exchange commissions at both ends of the transaction.

These findings, though subject to refinement as data improve, suggest that policymakers should pay attention to the complex challenges that developing countries face not only as countries of origin of migrants, but also as destinations. Designing appropriate policies, however, will require considerable efforts to improve data, and careful analysis of the socioeconomic impact of migration on wages, income distribution, gender, health, and migrants' rights.

We begin with an overview of recent trends in South-South migration, and then turn to estimates of remittances flows and a comparison of remittance costs in South-South versus South-North corridors. This is followed by a review of the literature on the determinants of, and the socioeconomic issues surrounding, South-South migration. 


\section{The Extent of South-South Migration}

A ccording to the United Nations, the global stock of international migrants has more than doubled over the past 40 years. Although as a share of population, it is estimated to have remained flat at around 1.5 percent, the number of migrants in the South may have increased by about 75 percent (Figure 1). The rise is due in part to a onetime jump in officially-recorded migrants that followed the breakup of the Soviet Union. At that time, what had been internal migration within the USSR was reclassified as international migration. The breakup also increased absolute levels of migration, as many people moved to the country with which they identified. Including migrants from the former Soviet Union, migration to the South accounted for 41 percent of worldwide migration, estimated at 191 million in 2005. When the former Soviet Union is excluded, this share falls to 32 percent.

A priori, one would expect to find that a large share of the migrants in developing countries are from other developing countries, as workers in industrial countries typically move to developing countries only to take up short-term, specialized positions, or in some cases for retirement. Empirical estimation on the extent of migration between developing countries, however, requires data on bilateral migrant stocks that are not readily available. The figures reported below are derived from an augmented and updated bilateral migration matrix originally created by the University of Sussex (for the Global Trade Analysis Project). This database (described in Parsons and others 2005) uses national censuses, population registers, national statistical bureaus and a number of secondary sources (OECD, ILO, MPI, DFID, UN) to compile bilateral migrant stocks for 162 countries. In an expanded version used for general equilibrium modeling, this database also estimated bilateral information for 64 additional countries for which the censuses had no information on sources of 
Figure 1. Migration Has Been Rising in the South, But at a Slower Pace than in the North

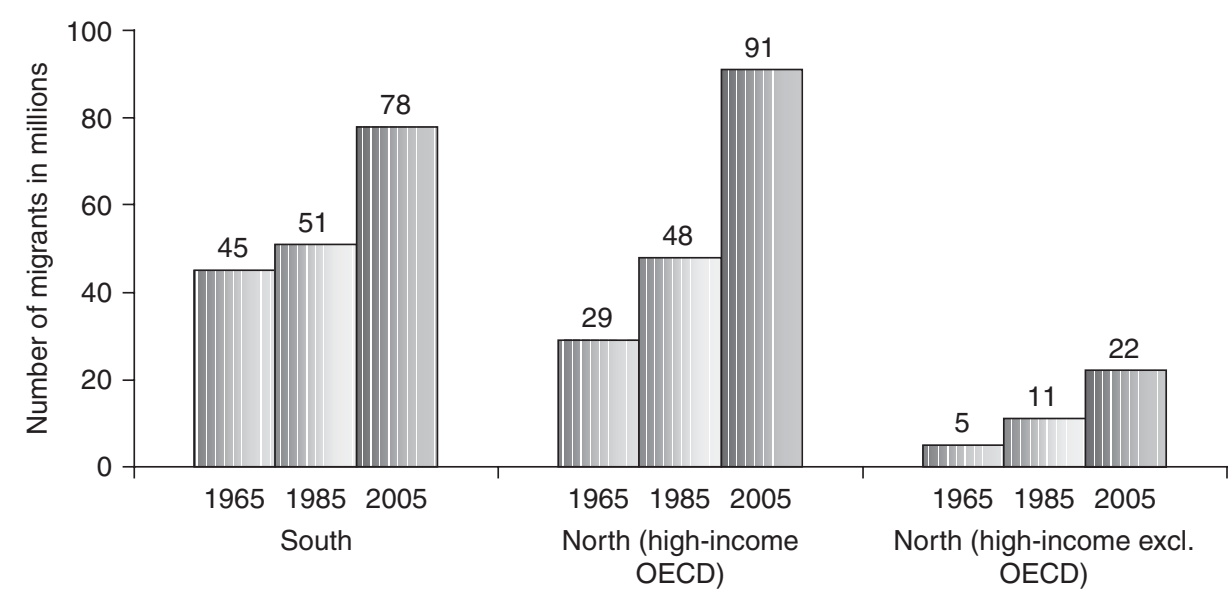

Source: Authors' calculations based on United Nations (2005).

migrants. We have updated the information on bilateral migrant stocks for 56 countries using the most recent census data. ${ }^{3}$ This exercise considerably improves the coverage of migrants in developing countries (see Appendix A). Also, because our purpose is to estimate South-South migration (and not necessarily to estimate detailed bilateral data for every country), we allocated unidentified migrants to only two broad categories, "other South" and "other North," thus avoiding stringent assumptions.

Some of the caveats on the underlying bilateral migration data discussed in Parsons and others (2005) also necessarily apply to this augmented data set. Even the widely-used data on overall migrant stocks from the United Nations is believed to underestimate global migrant stocks because of difficulties that arise from differences across countries in the definition of a migrant (foreign born versus foreign nationality), reporting lags in census data, and underreporting of irregular migration. These problems arise, in part due to a lack of standardized definitions and common reporting standards (and inadequate adherence to these standards where they exist), especially in low-income countries in the South but also in high-income countries that are not members of the OECD. Data on bilateral remittances are for the most part not available. Even where these are reported, they may not be accurate, because funds channeled through international banks may be attributed to a country other than the actual source country (Ratha 2005). Migration data, especially in developing

3. The data set on bilateral migration stocks and bilateral remittance flows worldwide are posted at www.worldbank.org/prospects/migrationandremittances. This dataset mostly consists of statistics on foreign-born wherever possible, and foreign nationals otherwise. The data are taken from national censuses. The original data are scaled (up or down as appropriate) to add up to the UNPD estimates of migrants stocks for 2005 . 
Table 1. Global Migrant Stocks (millions)

\begin{tabular}{lcccc}
\hline & \multicolumn{4}{c}{ Migrants in } \\
\cline { 2 - 5 } & $\begin{array}{c}\text { Developing } \\
\text { countries }\end{array}$ & $\begin{array}{c}\text { High-income } \\
\text { OECD countries }\end{array}$ & $\begin{array}{c}\text { High-income non- } \\
\text { OECD countries }\end{array}$ & Total \\
\hline Migrants from: & 73.9 & 61.8 & 20.1 & 155.8 \\
Developing countries & $(47 \%)$ & $(40 \%)$ & $(13 \%)$ & $(100 \%)$ \\
High-income OECD countries & 3.4 & 25.5 & 1.2 & 30.1 \\
High-income non-OECD countries & $(11 \%)$ & $(85 \%)$ & $(4 \%)$ & $(100 \%)$ \\
& 0.8 & 3.6 & 0.3 & 4.7 \\
Total & $(17 \%)$ & $(77 \%)$ & $(6 \%)$ & $(100 \%)$ \\
& 78.0 & 90.9 & 21.6 & 191 \\
& $(41 \%)$ & $(48 \%)$ & $(11 \%)$ & $(100 \%)$ \\
\hline
\end{tabular}

Source: University of Sussex and World Bank data based on UN (2005), individual country censuses, OECD (2006), and others. See Appendix A for details.

countries but also in the high-income non-OECD countries, are in need of serious overhaul in terms of availability, timeliness, quality, and cross-country comparability. ${ }^{4}$

However, in spite of these weaknesses, the database used for estimating South-South migration is the most comprehensive one available presently. ${ }^{5}$ Examination of this database suggests that South-South migration may account for 47 percent (74 million) of all migration from the South (Table 1). ${ }^{6}$ This estimated share is comparable to, although slightly smaller than, the 50 percent share estimated by World Bank (2005) using a previous version of the University of Sussex database. The United Nations Population Division (UNPD) also estimates that half of the migrants from developing countries migrate to other developing countries, again using the same database (UNGA 2006). The UNPD estimate of South-South migrants for 2005 , however, is only 61 million. ${ }^{7}$ This is smaller than our estimate, because it is based on a subset of data on migrants whose origin countries are identified. The true size of South-South migration is likely to be even greater than 74 million,

4. Proposed measures to improve overall and bilateral data on migration stocks include a survey of central banks and government departments (Ministry of Labor, Ministry of Interior), collecting information from international and bilateral institutions and academia, examining household surveys, and conducting literature search. Where available, comparing estimates of bilateral migration and bilateral remittances would also help in filling data gaps (for example, there are no bilateral migration data on Bangladeshi migrants in Kuwait and UAE, although Bangladesh reports substantial bilateral remittances from these countries). Finally, collaboration with major remittance service providers (Western Union, SWIFT) can help improve bilateral remittance data.

5. Indeed, given that data problems (e.g., undercounting of irregular migrants, missing data on migrants in censuses) are more severe in the South than in high-income countries, our estimates of SouthSouth migration may be an underestimate of the actual levels of migration in developing countries.

6. This share drops to 38 percent if migrants in the former Soviet Union are excluded.

7. UN (2006). Also cited in Margolis (2006). 


\begin{tabular}{|c|c|c|c|c|c|c|c|c|c|c|}
\hline & \multicolumn{10}{|c|}{ Migrants in } \\
\hline & $\begin{array}{c}\text { Latin } \\
\text { America \& } \\
\text { Caribbean }\end{array}$ & $\begin{array}{c}\text { East } \\
\text { Asia \& } \\
\text { Pacific }\end{array}$ & $\begin{array}{l}\text { South } \\
\text { Asia }\end{array}$ & $\begin{array}{c}\text { Europe \& } \\
\text { Central } \\
\text { Asia }\end{array}$ & $\begin{array}{l}\text { Middle East } \\
\& \text { North } \\
\text { Africa }\end{array}$ & $\begin{array}{c}\text { Sub- } \\
\text { Saharan } \\
\text { Africa }\end{array}$ & $\begin{array}{c}\text { High-income } \\
\text { OECD }\end{array}$ & $\begin{array}{c}\text { High-income } \\
\text { non-OECD }\end{array}$ & Total & $\begin{array}{l}\text { South-North } \\
\text { as percent } \\
\text { of total }\end{array}$ \\
\hline \multicolumn{11}{|l|}{ Migrants from: } \\
\hline $\begin{array}{l}\text { Latin America } \\
\text { \& Caribbean }\end{array}$ & 3.40 & 0.01 & 0.00 & 0.01 & 0.00 & 0.00 & 22.3 & 0.2 & 25.9 & 86.8 \\
\hline $\begin{array}{l}\text { East Asia \& } \\
\text { Pacific }\end{array}$ & 0.06 & 2.54 & 0.11 & 0.04 & 0.01 & 0.02 & 9.7 & 5.3 & 17.7 & 84.4 \\
\hline South Asia & 0.01 & 0.29 & 7.60 & 0.02 & 2.11 & 0.09 & 4.5 & 5.6 & 20.2 & 49.9 \\
\hline $\begin{array}{l}\text { Europe \& } \\
\text { Central Asia }\end{array}$ & 0.07 & 0.01 & 0.00 & 27.81 & 0.01 & 0.00 & 13.7 & 1.9 & 43.6 & 35.9 \\
\hline $\begin{array}{l}\text { Middle East \& } \\
\text { North Africa }\end{array}$ & 0.06 & 0.00 & 0.00 & 0.08 & 2.12 & 0.08 & 6.7 & 2.8 & 11.8 & 80.3 \\
\hline $\begin{array}{l}\text { Sub-Saharan } \\
\text { Africa }\end{array}$ & 0.01 & 0.00 & 0.01 & 0.01 & 0.01 & 10.02 & 4.0 & 0.5 & 14.5 & 30.7 \\
\hline $\begin{array}{l}\text { High-income } \\
\text { countries }\end{array}$ & 1.84 & 0.32 & 0.05 & 1.03 & 0.64 & 0.27 & 28.7 & 1.1 & 34.0 & 0.0 \\
\hline Total & 5.5 & 3.2 & 7.8 & 29.0 & 4.9 & 10.5 & 89.6 & 17.3 & 167.7 & \\
\hline
\end{tabular}

Source: University of Sussex and the World Bank (for details, see Appendix A). These data include only identified migrants—60.7 million in the South and 106.9 million in the North—for which both source and destination are known. These exclude 4.7 million migrants in the South and 4.9 million in the North for whom the source country is not known, as well as 12.7 million migrants in 37 countries in the South and 0.8 million migrants in 6 countries in the North about whom the respective censuses offer no information. 
Figure 2. South-South Migration is Greater than South-North Migration in Three Regions

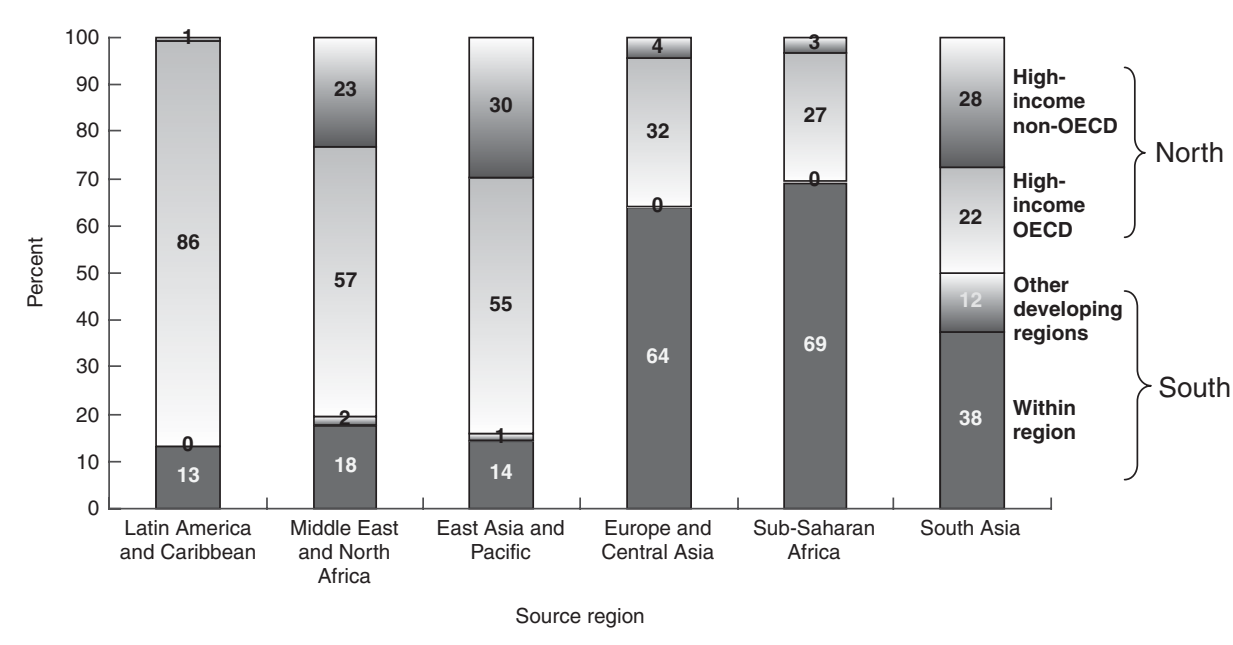

Source: University of Sussex and World Bank.

however, as available data do not fully capture irregular migration (see below). Migrants from the South are as likely to migrate to other developing countries as to the richer countries of the North. ${ }^{8}$

Table 1 indicates that only about two in five migrants from developing countries reside in the high-income countries of the Organization for Economic Co-operation and Development (OECD). Some 20 million (or 13 percent) are estimated to reside in high-income countries outside the OECD—among them Hong Kong (China), Saudi Arabia, Singapore, and the United Arab Emirates.

The regional distribution of South-South migration is presented in Table 2 and Figure 2. South-South migration is at least as great as South-North migration in three of the six developing regions. South-South migration is estimated to account for half of all outward migration from South Asia, 64 percent from Europe and Central Asia (although a portion of these are people who never crossed international borders but became migrants when new countries came into being after the breakup of the Soviet Union), and 69 percent from Sub-Saharan Africa. Also South-South migration is overwhelmingly intraregional. The share of migration to other developing regions is likely negligible in all regions except in South Asia. Even in South Asia, intraregional migration is estimated to be more than three times more common than migration to countries in other developing regions (Figure 2).

8. The latest data also reveal that the number of North-North migrants is about 31 million (or 16 percent of global migration), smaller than South-South migration. 
Figure 3. Top 20 Migration Corridors Excluding the Former Soviet Union

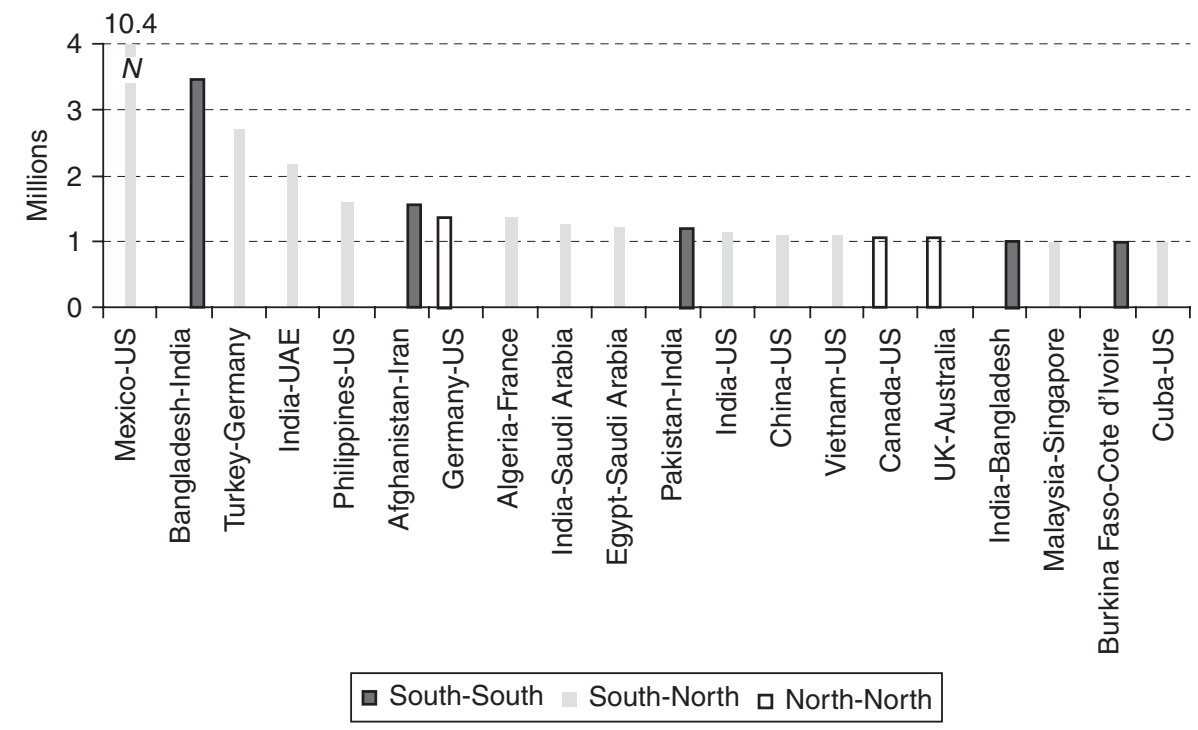

Source: University of Sussex and World Bank.

Although our data on bilateral migration are incomplete for many countries, available data reveal that some of the largest migration corridors are in the South (see Figure 3). After the Mexico-United States corridor, the next three largest are estimated to be RussiaUkraine, Ukraine-Russia, and Bangladesh-India. Many of these large migration corridors

\section{Figure 4. Top 20 Migration Corridors in the Former Soviet Union}

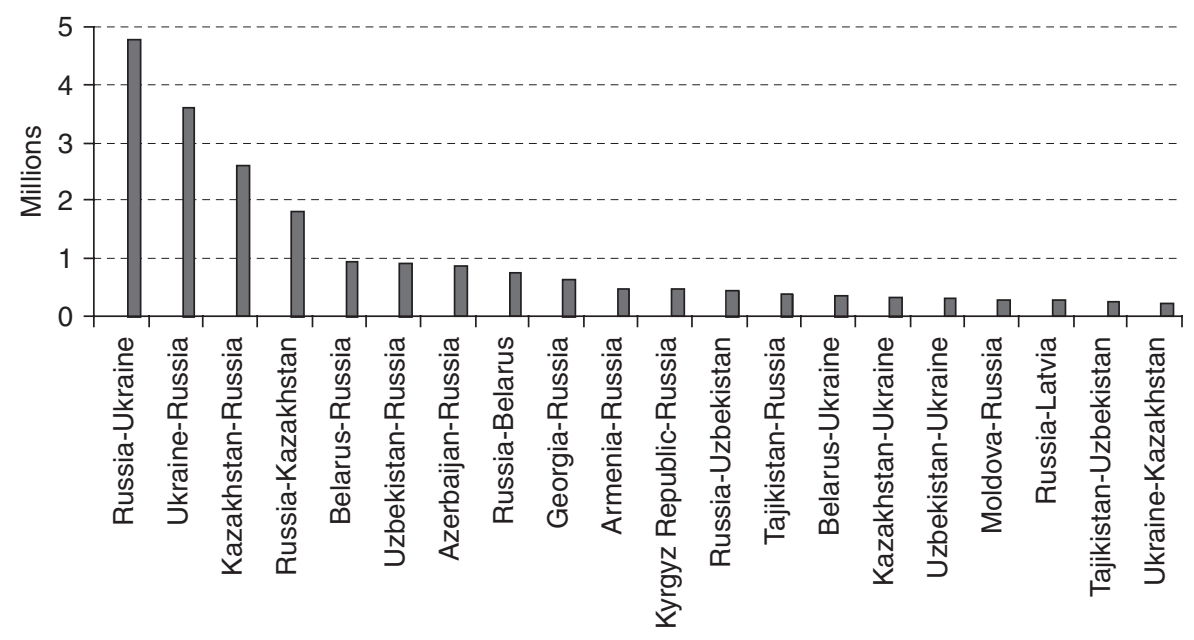

Source: University of Sussex and World Bank. 
emerged due to the partitioning of countries. When such corridors are excluded, the largest of the remaining corridors are not all South-North—some are North-North, others SouthSouth. India, Russia, and South Africa are well-known as receiving countries in the South. But, as shown in Figure 2, migration is widespread. There are many lesser-known receiving countries, including some with lower per capita income than the sending countries (see Table 4 in Chapter 3). 

CHAPTER 2

\section{South-South Remittances}

A ccording to the latest available data, officially recorded remittance flows to developing countries reached $\$ 188$ billion in $2005 .^{9}$ The true size of these flows, taking into account unrecorded flows through formal and informal channels, is believed to be at least 50 percent larger (World Bank 2005).

Like bilateral migration data, data on bilateral remittance flows are not readily available. To estimate South-South remittances, therefore, we devised three simple formulas to allocate to various source countries the recorded remittances received by each developing country (see Appendix B). A simplistic allocation scheme would assume that a country's remittance receipts from various source countries are proportional to its migrant stocks in those countries. ${ }^{10}$ On this basis, South-South remittances would amount to $\$ 55.4$ billion, or 29.5 percent of recorded remittances received by developing countries in $2005 .{ }^{11}$ However, this allocation rule assumes that all migrants send the same amount of remittances irrespective of where they live and work. Such an assumption clearly will overestimate remittances from the South, where per capita income levels are

9. Officially recorded remittance flows to developing countries approached $\$ 200$ billion in 2006 . See Migration and Development Brief 2 at www.worldbank.org/prospects/migrationandremittances.

10. This methodology has been applied by Harrison and others (2005) and World Bank (2005). Anecdotally, some top remittance service providers are also using such migration stock-based estimates of bilateral remittance flows for their business development and marketing strategy.

11. This estimate of South-South remittances (29.5 percent as a share of total remittances received by the South) is smaller than that of South-South migration (47 percent of migration from the South) because some of the top remittance recipient countries (e.g., Mexico) have a smaller share of their migrants in the South than in the North. Migration data in the South are often missing or under-recorded due to irregular migration or a lack of statistical capacity. 


\section{Table 3. Estimates of South-South Remittances Using Different Methods (US\$ billions)}

\begin{tabular}{lccc}
\hline & \multicolumn{3}{c}{ Remittances received by South countries } \\
\cline { 2 - 4 } & $\begin{array}{c}(1) \\
\text { Allocation rule } \\
\text { based on } \\
\text { migrant stocks }\end{array}$ & $\begin{array}{c}(2) \\
\text { Allocation rule based } \\
\text { on migrant stocks and } \\
\text { host-country incomes }\end{array}$ & $\begin{array}{c}\text { (3) } \\
\text { Allocation rule based } \\
\text { on migrant stocks, host- } \\
\text { country incomes, and } \\
\text { sending-country incomes }\end{array}$ \\
\hline Remittances from: & & & \\
Countries in the South & 55.4 & 17.5 & 34.3 \\
Countries in the North & $(29.5 \%)$ & $(9.3 \%)$ & $(18.2 \%)$ \\
Remittances received by: & 132.7 & 170.7 & 153.9 \\
All developing countries & $(70.5 \%)$ & $(90.7 \%)$ & $(81.8 \%)$ \\
& 188.2 & 188.2 & 188.2 \\
& $(100 \%)$ & $(100 \%)$ & $(100 \%)$ \\
\hline
\end{tabular}

Source: Authors' calculations.

much lower than in the North. When we use migrants' income levels as weights (using as a proxy per capita income in PPP terms in the destination country multiplied by the number of migrants), the estimate for South-South remittances drops to $\$ 17.5$ billion, or 9.3 percent of total remittances received by developing countries. That measure, however, overestimates North-South remittances at the expense of South-South remittances, because it implies that migrants send a fixed fraction of their income irrespective of their income level and with no consideration for the actual needs of their beneficiaries. So our third formula applies a remittance function (explained in Appendix B) that hypothesizes that the amount sent by an average migrant increases with the migrant's income, but at a decreasing rate. Ideally, the migrants' income should be taken from household survey data; but in the absence of such data, we use per capita GNI as a proxy for the migrant's income abroad. This assumption poses some difficulties in the cases involving migration to a country where the per capita income is lower than in the origin country. In such cases, we assume that the minimum remittance is at least as much as the per capita income of the origin country. ${ }^{12}$ That formula yields an estimate for South-South remittances of about $\$ 34.3$ billion, or 18.2 percent of total remittances received by developing countries in 2005 (Table 3$)^{13}$

12. Remittances should at least compensate for the counter-factual loss of income due to migration. Here we implicitly assume that the counter-factual loss of income equals the per capita income of the origin country.

13. In future work, a more general formulation that postulates remittance as a function of skills and poverty level, and differentiates between voluntary and non-voluntary migration may be more realistic. 


\section{South-South Remittance Costs}

High remittance costs are a major drain on the incomes of poor migrants. High costs, and lack of access to convenient remittance services, encourage migrants to use informal channels. Reducing remittance costs, therefore, has emerged as a major concern for policymakers (World Bank 2005). There is little information, however, on the cost of sending remittances from one developing country to another. To collect such information, we telephoned remittance service providers in selected South-South, South-North, and NorthSouth remittance corridors and asked for information on remittance fee for sending $\$ 200$, and foreign exchange conversion charges at both ends. The resulting data are summarized in Figure 5 and Appendix C.

It is often impossible to send remittances from one developing country to another through formal channels because of restrictions on outward remittances in the source country. Some countries (Bangladesh, India, Lesotho, and Morocco, among others) require migrants to obtain authorization before the central bank will process international remittances. In many countries, inward remittances also have to be reported to the authorities. In corridors where outward remittances are permissible, South-South remittance fees tend to be even higher than those for North-South (and often South-North) remittances

Figure 5. South-South Remittance Fees Tend to be Higher than North-South Remittance Fees

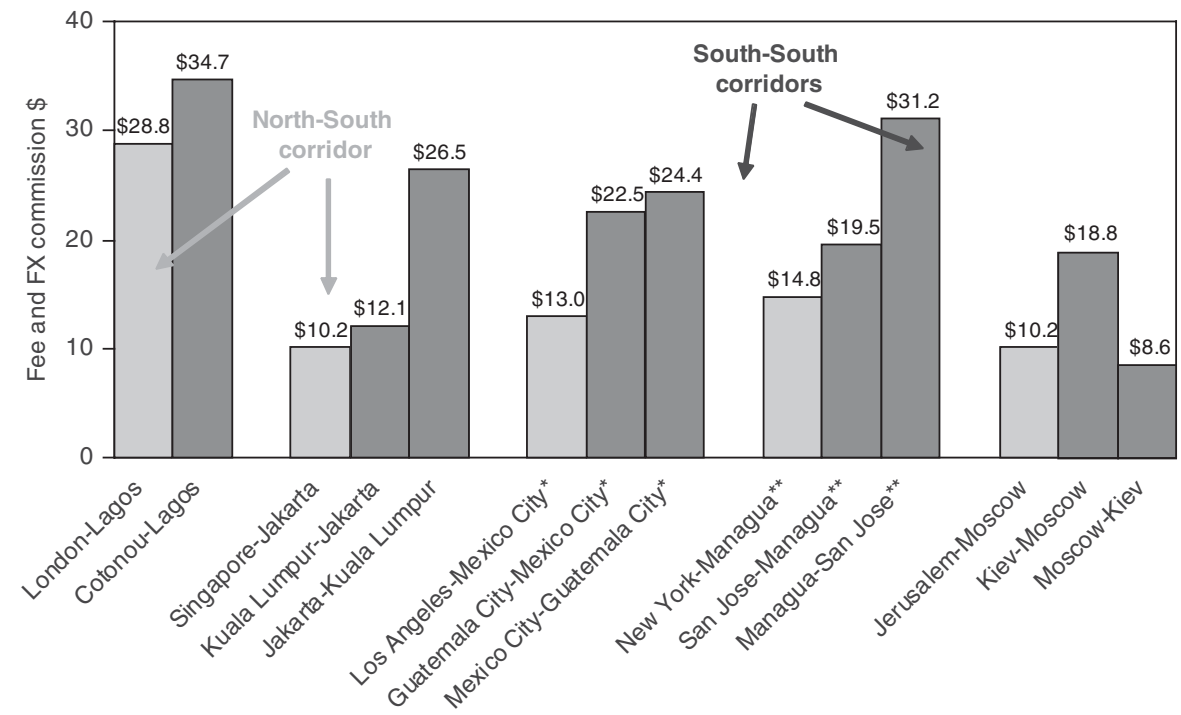

* These fees are the average of Western Union and other agencies.

*** The fees and foreign exchange (FX) commissions are from Western Union only, as indicated in Appendix C.

Source: Information collected through phone calls to agents on location ("mystery-shopping") during August 15-25, 2006, by DECPG staff. Fees include FX commission at source and destination. See also Appendix C. 
(Figure 5). Often remittance fees vary significantly in the same bilateral corridor depending on the direction of the flow. For example, the cost of remitting \$200 from Kuala Lumpur to Jakarta is about 6 percent, whereas that from Jakarta to Kuala Lumpur is more than 13 percent. Similarly the cost of sending money from Kiev to Moscow is more than double the cost of remitting in the reverse direction (Appendix C). ${ }^{14}$

South-South remittance costs tend to be high because of lack of competition in the remittance market in both the sending and the receiving countries. ${ }^{15}$ Often high foreign exchange commissions have to be paid at both ends, as the sender must purchase U.S. dollars (or another readily convertible currency) and the beneficiary must be paid in the local currency of his or her country. Usually the sender has very little information about the exchange rates applied by the remittance company at either end of the transaction.

Reducing costs is as important a policy imperative for South-South remittances as for North-South remittances. As has been discussed in great detail in World Bank (2005, chapter 6), remittance costs can be reduced by encouraging competition in the remittance market; by encouraging banks, microfinance institutions, credit unions, and post office saving banks to offer remittance services; by sharing existing payment platforms and networks; and by avoiding exclusive partnership arrangements between major money transfer operators and post office networks.

14. In the Kiev-Moscow corridor, Anelik provides money transfers in both directions at a fee of only 3 percent, suggesting that the huge difference in fees charged by other remittance service providers is not necessarily dictated by differences in the inherent cost of providing remittance services.

15. Where there is competition, as in high-volume corridors, South-South remittance fees may be lower than North-South remittance fees. This is the case in Mexico City, Kuala Lumpur, and Moscow, for example. 


\section{Determinants of South-South Migration}

I ncome, proximity, and networks are the major drivers of migration from developing to industrial countries (World Bank 2005). As South-South income differentials are relatively modest, proximity and networks likely have a proportionally greater impact. Motivations for South-South migration also include seasonal patterns and flight from ecological disasters or civil conflict. Other motivations, not recorded in the migration stock data given above, include transit to the North and petty trade. ${ }^{16}$ Agreements among countries have had comparatively little impact on South-South migration (Box 1). The following discussion is based on an analysis of available data, as well as a review of the economic literature.

\section{Proximity}

Almost 80 percent of identified South-South migration takes place between countries with contiguous borders (Figure 6). A large share of migration between countries with noncontiguous borders goes to countries that are relatively close. ${ }^{17}$ The costs (financial, social, and cultural) of migrating to nearby countries are likely to be lower than those of moving

16. Seasonal migration may or may not be included in the stock data, depending on when a census is taken and whether the national authorities distinguish between temporary and permanent residents. Similarly, temporary movements due to conflict or disaster may not be recorded in the migration data.

17. Using an index of distance developed by Rose (2004), 65 percent of the migration between countries that do not have a common border takes place between countries within the 40th percentile of countries ranked by distance. 


\title{
Box 1. The Role of Regional and Bilateral Agreements in Regulating South-South Migration
}

\begin{abstract}
Regional agreements among developing countries have made little progress in easing constraints on migration, compared with the major agreements among industrial countries (notably the European Union and the treaty between Australia and New Zealand). Despite explicit statements in support of greater freedom of movement, African agreements-among them the Economic Community of West African States (ECOWAS), the East African Community (EAC), and the Southern African Development Community (SADC) - have met with considerable difficulties in reaching agreement on specific steps to facilitate migration, or in implementing agreements once reached (Reitzes 2000).
\end{abstract}

Some progress has recently been achieved. Nationals of MERCOSUR (Argentina, Brazil, Paraguay, Uruguay, and Venezuela) theoretically have access to legal residence in any other member stateand Argentina's new immigration law obliges state authorities to simplify legal residence for foreigners in line with the MERCOSUR requirements. The common East African passport is in use by Kenyans, Ugandans, and Tanzanians, and visa-free movement of persons within West Africa is occurring under ECOWAS (Adepoju 2005). Yet, the provision of common travel documents does not guarantee legal residence or work rights. ${ }^{a}$ Further, the process has been hampered by lack of capacity to issue, register, and monitor documents at land borders (IOM and US Department of State 2005).

In addition to agreements, consultation processes have emerged to consider regional cooperation on migration issues. Examples include the Dakar Process in West Africa, the Bali Process in Southeast Asia and the Pacific, the Regional Consultations on Migration in Central and North America (the "Puebla Process"), the South American Conference on Migration (the "Lima Process"), and the Pacific Immigration Directors Conference (PIDC). The majority of these processes are focused on enforcement and security issues, although increasingly this is shifting to more facilitative approaches to labor movements, protection of migrants, and lobbying of destination countries to ease migration restrictions (IOM 2003, IOM 2004, IOM 2005a).

Bilateral migration agreements and memoranda of understanding are becoming more common among developing countries. Examples include the myriad bilateral agreements between Malaysia and Thailand, Vietnam's agreements with Eastern Europe and some neighboring countries (Lee 2005b), Argentina's agreements with Bolivia (1999) and Peru (1999) (Smith 2006, Petree 2006), and several agreements in Central Asia that account for most legal cross-border labor flows (IOM 2005b). Agreements with the Russian Federation have encountered difficulties, as many migrants able to move freely across the border have been unable to acquire the necessary work permits or have experienced prohibitive delays in processing. In general, however, there is little information available to evaluate the impact of these agreements, besides observations that some agreements do not provide adequate protection for migrants' rights (Wickramasekara 2006).

aFor example, the Commonwealth of Andean Nations created an Andean Migration Card that facilitates entry to a member country for up to 90 days but does not entitle the holder to work (El Universario Daily, June 11, 2006).

farther away. Because many South-South migrants lack adequate travel documents, they are restricted to overland migration. Ethnic, family, and religious ties link communities across borders, particularly in Africa, where colonial boundaries straddled tribal groups, but also in other parts of the world.

\section{Networks}

Ethnic, community, and family ties reduce the costs and uncertainties involved in migration. In Africa, migrant networks play a critical role in magnifying outflows once 


\section{Figure 6. South-South Migration Occurs Primarily among Neighboring} Countries

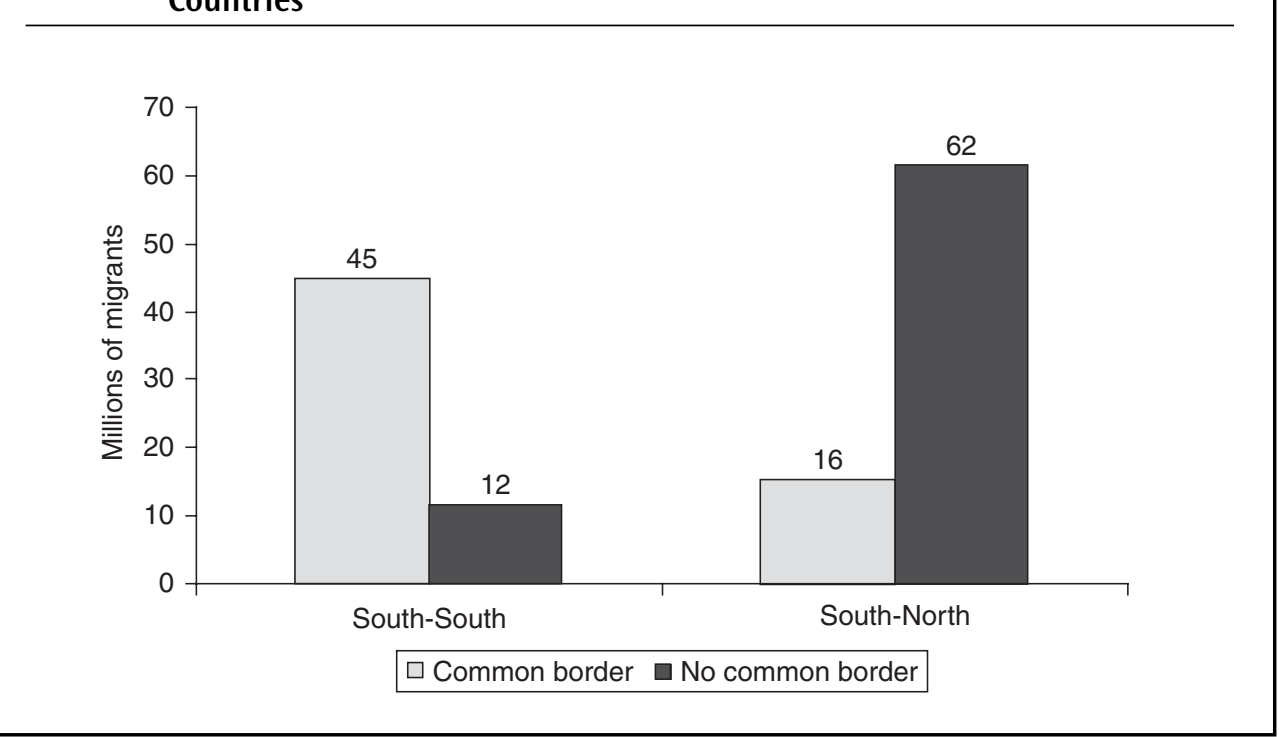

Source: Authors' calculations based on University of Sussex and World Bank bilateral migration data, and Rose (2004).

migration is underway (Lucas 2005). In some areas, migrant diasporas are longstanding: the arrival of significant number of Swazis, Tswanas, and Basothos in South Africa (as opposed to Swaziland, Botswana, and Lesotho) stems from movements of tribal groups in the nineteenth century (Solomon 1996). Evidence for the impact of networks can be found in linkages between nationalities and jobs. For example, Poles in Hungary have in the past frequently worked in mining and construction, while Slovakian women often worked in textiles (Juhasz 1999). In the Russian Federation, studies show that foreign workers in building, industry, and transport often come from the Ukraine. Migrants from Azerbaijan, China, and Vietnam often work in trade, and Chinese often work in agriculture (Rybakovsky and Ryazantsev 2005).

\section{Income}

Income differences between countries have some influence on South-South migration. The clearest example is seen in middle-income countries that have substantial numbers of immigrants from nearby low-income countries. For example, Argentina, Chile, and República Bolivariana de Venezuela attract migrants from Bolivia, Paraguay, and Peru ${ }^{18}$; Malaysia draws migrants from Indonesia; and South Africa attracts people from Lesotho,

18. In 2000, almost two thirds of Latin Americans living outside of their native country but within the region were in Argentina and Venezuela (Pizarro and Villa 2005). 
Table 4. Migration Patterns by Income Classification (millions)

\begin{tabular}{lcccccc}
\hline & \multicolumn{6}{c}{ Migrants in } \\
\cline { 2 - 7 } & $\begin{array}{c}\text { High- } \\
\text { income } \\
\text { OECD } \\
\text { countries }\end{array}$ & $\begin{array}{c}\text { High- } \\
\text { income } \\
\text { non-OECD } \\
\text { countries }\end{array}$ & $\begin{array}{c}\text { Low- } \\
\text { income } \\
\text { countries }\end{array}$ & $\begin{array}{c}\text { Middle- } \\
\text { income } \\
\text { countries }\end{array}$ & $\begin{array}{c}\text { Intra-income } \\
\text { group as \% } \\
\text { of South- } \\
\text { South }\end{array}$ \\
\hline Migrants from: & & & & & & \\
Low-income countries & 11.0 & 6.6 & 16.2 & 7.9 & 41.8 & 67.3 \\
Middle-income countries & 49.9 & 9.6 & 2.2 & 30.3 & 91.9 & 93.3 \\
High-income countries & 28.7 & 1.1 & 0.3 & 3.8 & 34.0 & \\
Total & 89.6 & 17.3 & 18.7 & 42.0 & 167.6 & \\
\hline
\end{tabular}

Source: University of Sussex and World Bank. See footnote to Table 2.

Mozambique, Namibia, and Zimbabwe. Fuchs and Straubhaar (2003) find a strong relationship between GDP levels and intra-Caribbean migration. Given the extreme poverty in many low-income countries, substantial migration flows also occur among low-income countries of different income levels. Consider, for example, migration from Burkina Faso, Mali, and Niger to Cote d'Ivoire and Ghana, and from Bangladesh and Nepal to India.

However, the available data indicate that differences in country income play a limited role in South-South migration. ${ }^{19}$ About 38 percent of identified South-South migrants come from countries with higher incomes than their host country. ${ }^{20}$ Of the migrants from lower-income countries, most go to countries with incomes only slightly above that of their home country. Only about 20 percent of identified South-South migration from lower- to higher-income countries is to countries with very large differences in income (that is, countries in the top 40 percent of income differences with the sending country). Examining migration patterns according to income groups, we estimate that more than two-thirds of South-South migrants from low-income countries are in other low-income countries. The corresponding figure for middle-income countries is 93 percent (Table 4).

Differences in country incomes are likely much greater, on average, for migrants traveling outside their native region than for intraregional migration, partly because larger income differentials are required to overcome higher costs associated with traveling over greater distances (geographic and cultural). In the lowest-income regions (Sub-Saharan Africa and South Asia), almost all identified intraregional migration from lower- to higherincome countries is to countries with only slightly higher income levels. The other regions show a larger share of intraregional migration going to countries with significantly higher

19. Differences in income between countries of origin and destination do not capture how income may affect incentives for all migrants. Individuals in higher-income countries may well migrate to take advantage of opportunities to earn higher incomes in lower-income countries.

20. However, of the total stock of identified migrants from higher-income countries, just over half reflect changes in legal status and population transfers attendant upon the breakup of the Soviet Union, while another, indeterminate, share left their homes due to conflict or natural disaster. 
income, reflecting the major middle-income migration poles of Argentina, Jordan, Malaysia, the Russian Federation, Thailand, República Bolivariana de Venezuela, and parts of Eastern Europe.

Several factors are likely to explain the muted impact of country income differences on South-South migration. Income differences among developing countries are of course much smaller than between developing and industrial countries. Lack of resources, limited access to travel documents (see below), and the location of networks may limit migrants' ability to travel far beyond neighboring countries, where income differences are often low. In Africa more emigration (relative to population) occurs from low-income than middle-income countries, and most emigrants from low-income countries go to neighboring countries, unlike emigrants from middle-income countries, more of whom go to industrial countries (Lucas 2005). Seasonal migration may occur regardless of income differences. There also is some evidence, largely from studies of internal migration, that migration between areas of similar income levels can help families diversify income sources and thus reduce risk. ${ }^{21}$

\section{Seasonal Migration}

Some individuals migrate to take advantage of seasonal weather patterns. In the late nineteenth and early twentieth centuries Indian laborers departed for Burma between October and December, returning between March and May, to escape the monsoons and satisfy the demand for seasonal labor in agriculture and the rice mill industry (Satyanarayana 2001). Today, thousands of Nepalese farmers cross into northeast India during planting and harvesting seasons (Khadria 2005). In West Africa, temporary migration may be the principal form of cross-border labor mobility, owing to regional variations in the seasonality of agricultural production (Beals and Menezes 1970, Lassailly-Jacob 2006, World Bank 1993). Seasonal migration also occurs in South-North migration, as exemplified by the northern migrations of Mexican farm workers for harvests in the United States. However, seasonal migration may be more prevalent in South-South migration, because borders are more porous and agriculture weighs more heavily in the economy. By contrast, temporary migration divorced from seasonal agricultural employment is common in both SouthSouth and South-North migration. ${ }^{22}$

\section{Transit}

Some developing countries receive migrants in transit to industrial countries. Mexico has become an important destination for migrants from Central America (Castillo 2006), both as a place to settle and as a temporary stop on the way to the United States. The Czech

21. See World Bank (2005) and Lucas (2005).

22. Seasonal migration may not be reflected in the stock data on migration, but such migration may generate significant welfare gains. 
Republic and Poland are important transit countries for migrants wishing to enter Germany (Horakova 2000, Okólski 2000). West African migrants travel to Cape Verde, The Gambia, and Guinea to obtain false documents en route to Europe (Adepoju 2002). Turkey and North Africa serve as transit countries for migrants to southern Europe (Baldwin-Edwards 2006). Middle-income developing countries also serve as a springboard for professionals from lower-income countries bound for destinations in the North, as exemplified by nurses from Ghana who work in South Africa for one or two years before migrating to Canada, the United Kingdom, or the United States. A nurse registered in South Africa can gain full registration status in the United Kingdom (Vujicic and others 2004). Migration for transit is not reflected in the migration stock data presented above.

\section{Petty Trade}

Individuals also cross borders to sell small amounts of goods, for example, as informal street traders. (Such individuals are not strictly classifiable as migrants.) Longstanding arrangements, such as the 1950 agreement between India and Nepal allowing free passage and trade, can operate with little monitoring and by all accounts are trouble free (IOM 2003). For many years, traders from Mozambique and other locations in southern Africa have regularly crossed into South Africa, usually on visitor visas that do not permit trading (Peberdy 1998). Angolans cross into Namibia for various reasons, including trade (Nangulah and Nickanor 2005). What is called "suitcase trading" by migrants from neighboring countries in the north, while not constituting migration in its strict sense, has reached huge volumes in Turkey (IOM 2005a). In Latin America, the economic crises of the 1980s increased the number of self-employed migrants and of migrants working in services and commerce (Pellegrino 2000). Twice a week, a key border town in the Dominican Republic allows Haitian traders access to markets without immigration inspection (IOM 2005c).

\section{Conflict and Disaster}

Migrants escaping from war often go to other developing countries, often as a first step in seeking asylum. In fact, most refugees and asylum seekers are located in developing countries. At the end of 2005, the number of refugees in the developing countries was three and a half times that in the developed countries (UNHCR 2006). The number of refugees and asylum seekers recognized by the U.N. High Commissioner for Refugees fell from 13 million in 1997 to 9 million in 2005 (Table 5). ${ }^{23}$ Although the UNHCR data do not include all people displaced over international borders because of conflict, the decline in refugees and asylum seekers does reflect some reduction of political conflicts in Africa, where the number of refugees fell from 5.4 million in 1990 to about 3 million in 2005 (UN 2006). Civil violence also has been a major driver of migration in Latin America, where Colombians account for

23. Because we are studying cross-border migration we exclude internally displaced persons, whose plight may be no better than international refugees. When internally displaced persons are counted, the total falls from 19 million in 1997 to 16 million in 2003, before rising back to 19 million in 2005 . 
Table 5. Refugees and Asylum Seekers (millions)

\begin{tabular}{lrrrrrrrrr}
\hline & 1997 & 1998 & 1999 & 2000 & 2001 & 2002 & 2003 & 2004 & 2005 \\
\hline Asylum & & & & & & & & & \\
seekers & 1.0 & 1.0 & 1.0 & 1.1 & 1.1 & 1.1 & 1.0 & 0.8 & 0.8 \\
Refugees & 12.0 & 11.5 & 11.7 & 12.1 & 12.1 & 10.6 & 9.7 & 9.6 & 8.4 \\
Total & 13.0 & 12.5 & 12.7 & 13.2 & 13.2 & 11.7 & 10.7 & 10.4 & 9.2
\end{tabular}

Source: UNHCR.

the largest number of intraregional migrants. The rise in the number of international migrants in Latin America during the 1980s, and the decline in the 1990s, was mainly attributable to movements of refugees and displaced persons during the conflicts of the 1980s and their return once peace was restored (UN 2004).

Ecological disasters sometimes provoke South-South migration. The Red Cross estimated that in 1999 as many as 25 million people had been displaced by environmental disasters, including people displaced within countries, and this is likely to grow (Myers 2005). That figure covers a spectrum of issues with varying mixtures of human and natural causes, ranging from displacements due to political decisions (dam construction), pollution (the degradation of the Niger delta due to oil spills), desertification (China, Libya, Morocco, Tunisia), soil erosion (Turkey), and drought (the Sahel). 



\title{
Socioeconomic Dimensions of South-South Migration
}

\begin{abstract}
nalyzing the welfare implications of South-South migration is fraught with difficulties, $A$ in part because of the tentative nature of the migration data, in part because of 1 insufficient information on economic and social conditions in many developing countries. This chapter reviews selected topics on the socioeconomic dimensions of SouthSouth migration, including wages, irregular migration, health, gender, trafficking, and unstable migration flows. We begin with a model-based analysis of the wage impact, but the bulk of the discussion is based on the economic literature.
\end{abstract}

\section{Wages}

It is difficult to judge the impact of migration on labor-market conditions in destination countries. In industrial countries, estimating the relationship between migration and wages is difficult principally because it is hard to control for other factors affecting wages and for endogeneity-migration affects wages, but wage levels also affect migration decisions. In most developing countries, the basic data required to gauge the impact of migration on the labor market - time series of migration flows or stocks and wage data—are lacking. Thus most analyses are based on anecdotal evidence; some are wholly unsupported. ${ }^{24}$

24. For example, Solomon (1996) reports union complaints about migrants on South African farms working for shelter and a plate of food a day, while remaining resistant to union activities due to fear of exposure. An influx of poorly-educated Nicaraguan migrants contributed to growing wage inequalities in Costa Rica in the 1990s (World Bank 2006). 
Table 6. Change in Wages in Destination Countries from Increased South-North
and South-South Migration (percent change from baseline)

\begin{tabular}{lcc}
\hline & South-North migration & South-South migration \\
\hline New migrants & 2,314 & 60 \\
Natives & -0.7 & 0 \\
Existing migrants & -13 & -6.6
\end{tabular}

Source: Authors' calculations.

To gain insight into the differential impact of South-South versus South-North migration, we used a global general equilibrium model to perform two model-based simulations of an increase in migration. The first simulation assumes that the number of workers migrating from developing to industrial countries increases by an amount equal to 3 percent of the labor force of industrial countries by 2025 (a rise of 14.2 million migrant workers). ${ }^{25}$ The second assumes the same increase in the number of migrants from developing countries, except that they go to other developing countries. (New migrants are allocated in proportion to the stock of existing migrants.) For South-North migration, the new migrants enjoy a gross increase in wages (before accounting for any rise in taxes or subtracting remittances) of more than 2,300 percent (Table 6). For South-South migration, where wage differentials between origin and destination countries are much smaller, the new migrants experience a comparably small (albeit still significant) rise of 60 percent. ${ }^{26}$

The much greater rise in wages for South-North migrants should be adjusted to more closely approximate the welfare gains involved. South-North migrants experience much greater increases in the cost of living than do South-South migrants, reducing the relative welfare advantage obtained from South-North migration..$^{27}$ In general, higher prices in the rich countries imply that welfare gains for migrants from developing countries should be divided by three, on average. Assuming that South-North migrants' welfare gains are reduced by this ratio and that South-South welfare gains are not adjusted, South-North migration would still be more than ten times more profitable than South-South.

Two other considerations that are more difficult to quantify reduce the welfare advantage of South-North relative to South-South migration. Many South-North migrants are likely to experience higher taxes in the rich countries than they did in their countries of origin. Developing-country tax systems are diverse, and many have higher marginal tax rates than in industrial countries. However, enforcement can be weak, and many migrants may have fallen completely outside the tax systems in origin countries. Second, South-South migration is usually less expensive than South-North migration,

25. This simulation is described in detail in World Bank (2005, chapter 2). Some minor changes have been made to reflect data revisions since last year.

26. Note that the increase in new migrants' household income reported by the World Bank (2005) is only about 600 percent, reflecting higher taxes in the rich countries, remittances sent to developing countries, and the lack of capital income assumed in the scenario.

27. World Bank (2005) provides a discussion of cost-of-living adjustments to the welfare gains from migration that are appropriate in this context. 
because distances are shorter (as a large majority of South-South migration is to nearby countries) and air travel is less necessary.

The impact of the migration shock on natives and existing migrants is smaller for South-South migration than for South-North migration. Natives in developing countries see no significant change in wages from greater South-South migration, while existing migrants experience a decline of more than 6 percent. In the South-North migration simulation, natives see a decline of 0.7 percent in wages and existing migrants a decline of 13 percent. The net change in the labor force for developing countries is necessarily zero for the South-South simulation; for the South-North simulation it is positive. Even at the regional level, the impact on wages of natives and existing migrants is minimal, as so much of South-South migration occurs within regions.

Obviously this exercise is subject to many qualifications. The data on South-South migration are weak, the parameters driving the results (such as the elasticity of wages with respect to changes in the supply of workers) have only a limited empirical foundation, and a significant share of South-South migration is unrelated to income differences between countries. The model cannot account for many issues that affect the wage gains from migration (such as the legal status of migrants, effects of migration on workers' productivity, the potential impact on investment of a greater supply of workers, and adjustment costs faced by migrants). Moreover, an analysis of the welfare gains from migration would have to consider broader issues, such as the costs and benefits of diversity, the costs of separation from family and friends, improvements in the flexibility of the labor force due to migration, the implications of skilled migration, the risks of exploitation and abuse, and the potential for increasing returns to scale (the model assumes constant returns to scale). Nevertheless, the simulations provide a ballpark estimate of the relative economic advantages of South-North migration over South-South migration.

\section{Irregular Migration}

Irregular migration is by its nature difficult to measure, particularly in developing countries. Some observers claim that it is more common in South-South than in South-North migration flows. It is likely that a higher proportion of South-South than South-North migration occurs without valid documents (Weiss-Fagan and Bump 2005; Long, Le Roux, and Wecker 2006; Adepoju 2005). Several factors, related to some degree to combinations of strict (or unclear) rules against legal immigration and weak enforcement, conspire to make irregular migration common in developing countries:

(a) In many developing countries, as in some developed countries, high taxes and regulations constrain flexibility in employment, encouraging employers to hire irregular migrants (Juhasz 1999 describes the Hungarian example). Despite strict immigration laws and work permit requirements in many countries in the South, there is little evidence that governments in the South apply sanctions on employers when illegal migrants are hired.

(b) In many developing countries rules governing immigration are unclear. They may be supported by administrative arrangements or executive decrees rather than legislation. In any event, they are generally less well articulated than immigration 
rules in industrial countries. ${ }^{28}$ The lack of transparency creates uncertainty over legal arrangements, reducing the incentive to take the often costly steps to migrate legally.

(c) Where migration rules are clear they are often very restrictive, very burdensome (in terms of administrative requirements), or very costly, encouraging irregular migration. For example, some Asian countries have rigid controls on foreign workers and prohibitions against settlement and family reunion (Athukorala 2006). Legal immigration to Argentina requires a work contract arranged in advance, and employers are required to provide housing. Most immigrants circumvent these cumbersome regulations by finding work in unregulated sectors of the economy (Doomernik 1998). In South Africa, employers were required to pay a contract fee of $\$ 400$ for a sixmonth period, and legal migration was strictly regulated to direct workers to specific industries, leading to substantial irregular migration (UN 2004). Russia recently increased the cost of residence permits; in conjunction with visa-free arrangements for visitors from CIS countries, the increase has led to higher irregular migration (Andrienko and Guriev 2005). Visa processing fees may also be prohibitive for unskilled migrants (Long, Le Roux, and Wecker 2006). Overall, few opportunities exist for legal immigration outside short-term work arrangements with little opportunity to achieve permanent residence (Abella 2005, IOM 2005a) ${ }^{29}$

(d) A lack of resources makes it difficult for many developing countries to police their extensive land borders. For example, see IOM (2005c) on the border between Haiti and the Dominican Republic; IOM/USDOS (2005) on lack of border controls in Kenya, Tanzania, and Uganda; and Crush and Williams (2004) on South Africa's inability to limit irregular migration despite devoting significant resources to improving border controls.

(e) Difficulty in obtaining travel documents from origin countries can also encourage irregular migration, particularly of poorer migrants. Passports can be costly. According to a survey of 127 countries undertaken in 2005, the cost of obtaining a passport in 14 of those countries was 10 percent or more of annual per capita income (McKenzie 2005). ${ }^{30}$ The cost of providing documents has risen with the international agreement to provide machine-readable passports and pressures to employ biometrics to check identities. ${ }^{31}$ Demands for bribes, bureaucratic delays

28. Some developing countries have recently established comprehensive regimes for managing immigration, for example Argentina (in 2004), the Dominican Republic (2004), Indonesia (2005), and Morocco (2003). But in some cases the new laws still lack implementing regulations and procedures (IOM 2005c, IOM 2006).

29. However, some countries, for example Argentina, Malaysia, and Thailand, have undertaken drives to provide amnesties or legalize the status of large groups of irregular migrants (Asis 2005a, OECD 2001).

30. For poor Haitians seeking work in the sugar cane fields in the Dominican Republic, a passport can be prohibitive because of administrative complexities and high costs ( $\$ 125$ compared with earnings of less than $\$ 100$ a month in the Dominican Republic and \$1-2 a day in Haiti), reported by the IOM office in Port au Prince.

31. As industrial countries increasingly employ biometrics according to ICAO's standards, developing countries need the same features, also to comply with regional integration agreements, to gain visawaiver status with industrial countries, and more broadly to enhance the legitimacy and security of their national identity document abroad (Harns 2006). 
in issuance, and the need to travel long distances to apply for passports also reduces access to passports, increasing irregular migration.

(f) Countries where large shares of workers are in the informal sector are in a poor position to control irregular migration through policing employers or recruiting agencies. In the Russian Federation, for example, the breakdown of law enforcement during the transition to capitalism was accompanied by a rise in irregular migration related to participation in the shadow economy, illegal businesses, and criminal activities (Krassinets 1998).

Irregular migration can leave individuals open to exploitation (see the section on trafficking, below) and abuse by authorities. The high rate of irregularity in South-South migration, coupled with weaker law enforcement in the South than in the North, implies that South-South migrants may face greater risks than South-North migrants. ${ }^{32}$ In South Africa irregular migrants are particularly vulnerable to harassment by police (Crush 2003) and to employers who use threats of exposure to limit complaints about poor working conditions (Kanyenze 2004). Irregular migrants can also be more vulnerable to being robbed in transit, with or without the connivance of authorities. For example, the police and courts are considered ineffectual in stopping theft on the border between Lesotho and South Africa (Kynoch and Ulicki 2000), and the Inter-American Commission on Human Rights reports that corrupt officials in Guatemala and Mexico collaborate with smugglers and traffickers in the abuse of migrants (Lawson 2000).

\section{Health}

Although particularly vulnerable to disease and capable of spreading disease through their travels, migrants lack access to medical assistance. For example, in Africa the largely temporary nature of migration, with migrants returning home to their families on a regular basis, provides a corridor for infection (Brummer 2002). Regions with higher seasonal and longterm mobility have higher rates of HIV infection, particularly along transport routes and in border regions (UNAIDS 2006). Migrants also may be more vulnerable to acquiring the infection due to opportunities for sex with multiple partners, including with commercial sex workers (Kulis and others 2004). Detailed studies of African migration find that the likelihood of HIV infection rises with migration and with the concentration of migrants in destination countries. ${ }^{33}$ The spread of tuberculosis in southern Africa also appears to be influenced by migration patterns (MIDSA 2004), as when mine workers from South Africa spread it to

32. On the other hand, supportive networks may be more common in receiving countries in the South (because such a large share of South-South migration occurs between neighboring countries), which would tend to reduce risks.

33. In villages near Matam, a city in northern Senegal, 27 percent of men returning from international migration were HIV positive, compared with less than 1 percent for nonimmigrant males, and interviews of women confirmed a high proportion of HIV infection from migrant husbands (Thiam, Pery, and Piche 2004). Studies of districts in South Africa found HIV prevalence of 24 percent among migrants and partners, versus 15 percent among nonmigrants and their partners (Lurie 2004). In Mali, a rise in HIV infection and AIDS cases was partly explained by migration from neighboring countries (World Bank 1993). 
neighboring countries in the 1950s and 1960s (Anarfi 2005). Evidence of disease transmission through migration is increasing in Asia. A few sending countries (notably the Philippines) require HIV tests of departing, and occasionally returning, migrants (IOM 2005b).

While the spread of disease through migration is common to North and South, the consequences can be greater in the destination countries of the South because of the more generalized lack of access to health care services. Few developing countries have incorporated migrant health issues into their public health policies and AIDS planning (UNAIDS 2006, IOM 2005b). By contrast, UNHCR found a lower incidence of HIV infections in refugee camps in Kenya than among the host-country population, owing to the availability of health care services in the camps (IOM 2005b).

\section{Gender}

Globally the number of female migrants is estimated to have increased from 35.3 million (or 46.8 percent) in 1960 to 94.5 million (or 49.6 percent) in 2005 . The share of women among migrants in developing countries was about 38.9 million (or 51 percent) in 2005, compared to 46.2 million (or 51 percent) in the high-income OECD countries and 8.7 million (or 40 percent) in the high-income non-OECD countries. ${ }^{34}$

The share of women in South-South migration varies considerably by migration corridor. ${ }^{35}$ In some countries the increase in female migrants reflects changes in labor demands. For example the entry of women into the workforce in some middle-income countries has created a growing need for domestic workers (Asis 2005a). Difficult economic conditions in other developing countries have led to a greater participation of women in the informal economy-as cross-border traders or street vendors, for example. Moldovan women migrate to Turkey and the Russian Federation to market produce and work as small-scale produce vendors (World Bank 2000). By contrast, a number of developing countries (such as Afghanistan, Algeria, Bangladesh, Democratic Republic of the Congo, Gabon, Libya, Pakistan, Sudan, Uganda, and Swaziland) have policies to discourage or forbid women from emigrating (McKenzie 2005, Battistella 2003). In other countries changes in the sectoral composition of labor demand have affected the share of female migration. In South Africa, work in the mines, which is performed largely by men, accounted for a large share of immigrants in the 1960s and 1970s. However, the share of women in migration to South Africa has increased as the mines have reduced their reliance on foreign workers (Lucas 2005).

The growing importance of domestic workers in migration underlines concerns about exploitation. Confinement to private homes, poor language skills, insufficient knowledge

34. In "less developed regions" as defined by the United Nations, the share of women was 44.7 percent in 2005, well below the 52.4 percent in the other regions.

35. Consider these findings, for example. Two-thirds of migrants from Sri Lanka in 1998 were women (Haque 2005). Women make up the majority of the Colombians in Ecuador and Venezuela, Chileans and Paraguayans in Argentina, and Peruvians in Chile (Pizarro and Villa 2005). The share of women among Bolivian migrants to Argentina has risen since the 1980s (Bastia 2005). Women accounted for 70 percent of newly hired Filipino overseas workers (Battistella 2003). Lee (2005a) notes the rising share of women in contract migration in East Asia. 
about their rights, and rules under some migration programs that allow employers to confiscate passports or otherwise control the migrants' ability to stay in the country-all have led to sexual harassment and abuse (Wickramasekera 2002). In some countries in Asia, for example, the entry, stay, and work of migrants are linked to a specific employer, thus limiting migrants' ability to change employment and increasing their vulnerability (Asis 2005b). ${ }^{36}$ Women have unequal access to formal migration channels-because they have less access to information and because there are fewer established migration routes and networks to serve them. Thus they may be more vulnerable to trafficking (Theuermann 2005).

Migrant vulnerability to HIV and other infections can also be highly gender-specific. In Cameroon, a study of urban populations found a greater correlation between male mobility and HIV risk than between female migration and HIV prevalence. ${ }^{37}$ On the other hand, South Africa reported at the end of 2003 a surprisingly high HIV prevalence among female partners of men who had migrated and failed to send home money, forcing the women to sell sex to support their families (UNAIDS 2004). The International AIDS Conference in Bangkok in 2004 identified a particular prevalence of HIV among female migrant workers in Asia. Most affected were poorer migrants working in the domestic and sex industries, mostly women, with no legal status, limited access to medical care, and the threat of dismissal and deportation should they fall ill.

\section{Trafficking in Persons}

Estimates of the number of people trafficked across international borders vary widely and are subject to considerable uncertainty, given the clandestine nature of trafficking and the diverse definitions used for trafficking by reporting institutions. ${ }^{38}$ Victim surveys show that most trafficking originates in developing regions but plays itself out in low- and highincome countries alike. ${ }^{39}$ In Sub-Saharan Africa, where irregular migration is probably the dominant form of migration (Lucas 2005), children are trafficked for farm labor and domestic work, and women and young persons for sexual exploitation. UNICEF estimates that up to 200,000 children are trafficked annually in West and Central Africa, while in East

36. The Kafil system common in the Middle East ties migrant labor recruitment to the employer, who is responsible financially and legally for the worker. Workers who break their contract must leave the country immediately at their own expense. Typically, employers confiscate the passports of their workers to enforce controls (Baldwin-Edwards 2006).

37. The study found that in one year migrating men had a higher incidence of HIV than those remaining home; incidence increased the longer they were absent from home (to 7.6 percent among those away for longer than 31 days, compared with 3.4 percent for less than 31 days and 1.4 percent among those who did not leave). No similar correlation was found between women's mobility and HIV infection. See IOM 2005 for a summary of the study by Lydie and others (2004).

38. For example, Wickramasekara (2002) reports that organized gangs worldwide are estimated to traffic some four million people every year; the International Labour Organization (2005) believes that there are 2.45 million persons in forced labor as a result of trafficking. The US Department of State estimates some 600,000 to 800,000 persons trafficked across international borders (U.S. Department of State 2005).

39. See IOM's database "Counter Trafficking Module" and the database of the Belgrade Regional Clearing Point supported by Organization for Security and Cooperation in Europe and managed by IOM (RCP 2003). 
Africa, women are abducted from conflict areas to work in the sex trade (Adepoju 2005). Developing countries also serve as important transit points for conveying trafficked migrants to industrial countries. For example, Albania is an important link in trafficking networks that force women to work in the sex industries of Western Europe (World Bank 2003). India serves as a major destination country for women trafficked in South Asia; from India many are transited to countries in the Middle East (Haque 2005).

The frequency of trafficking in South-South versus South-North migration is unclear. On the one hand, weaker law enforcement, and perhaps a greater frequency of irregular migration, may make trafficking more common in developing countries. On the other, higher returns in industrial countries may increase the supply of trafficked women and children there. In one example, Lee (2005a) focuses a discussion of cross-border trafficking in East Asia on flows of migrants to the richer countries, rather than between the less developed countries. The United Nations (2004) finds that generally persons are trafficked from developing to industrial countries, or toward neighboring countries with marginally higher standards of living.

\section{Instability}

While not captured in the stock data presented earlier, migration flows among developing countries may tend to be less stable than flows from developing to industrial countries, for three reasons. First and most important, South-South migration flows are unstable because of the high incidence of conflict in many parts of the developing world. Net migration rates are extremely unstable in Africa due to conflict (Lucas 2005), and several countries have alternated between being net receivers of immigrants and net senders of emigrants over the past 30 years (Blaise 2006).

Second, migrants have been subject to mass expulsions or other pressures to leave, often in response to economic downturns. Expulsions of non-nationals in Africa have occurred in Benin, Chad, Cote d'Ivoire (three times), Equatorial Guinea, Gabon, Ghana, Guinea, Liberia, Nigeria (twice), Senegal (twice), Sierra Leone, and Uganda (Adepoju 2002 and Lassailly-Jacob 2006). Ethnic Chinese left Vietnam en masse at the end of the 1970s; Tunisians and Egyptians left Libya; Iranians and Iraqis left each other's country; and ethnic Turks left Bulgaria in the 1980s. Yemenis left Saudi Arabia; Haitian sugar workers left the Dominican Republic; and the Muslim Rohingyas left Burma for Bangladesh in the 1990s (Van Hear 1993). During the East Asian crisis Malaysia and Thailand (as well as high-income Republic of Korea) attempted to cut back on migrant inflows and expel illegal migrants, with only limited success (Athukorala 2006).

Third, South-South migration may be more affected by economic cycles than SouthNorth migration. Developing countries experience more extreme economic cycles, on average, than do industrial countries. Also, the incentive to migrate is subject to threshold effects (that is, below a certain level, income differences are no longer adequate to encourage migration), and the smaller income differentials among developing countries can mean sharp changes in migration incentives with booms and recessions. ${ }^{40}$ For example, migration from

40. However, migration flows to industrial countries are also affected by cyclical conditions due changes in the probability of employment. 
Paraguay to Argentina was found to be more responsive to economic cycles than migration from poor to rich nations (Parrado and Cerruti 2003). Lucas (1987) finds that improved economic opportunities at home significantly discourage migration to the South African mines.

Instability due to conflict and expulsions can have high costs for migrants and can represent a financial and security concern for countries hosting refugees. ${ }^{41}$ Sudden inflows of return migrants may also impose significant costs on origin countries. The impact of returns from other developing countries has received little scrutiny, but some insight can be gained by studying returns from rich countries. For example, the Gulf War of 1990-1 led to a return inflow to Jordan equal to 9-10 percent of the population, boosting unemployment, increasing demands on social services, and adding to the shortfall in water supply. ${ }^{42}$ Poverty levels rose, because many of the returnees were poor, remittances declined, and former remittance recipients now had to support returned family members. Nevertheless, the return generated some long-term benefits owing to the arrival of large numbers of professionals and skilled workers. Some returnees brought with them substantial financial resources, which contributed to an economic boom toward the end of 1992.

By contrast, the welfare implications of instability of migration flows resulting from economic cycles are unclear. Migrants who find their expectations of higher incomes disappointed because of a sudden change in the economic climate are of course harmed. Nevertheless, some workers gain; those who choose not to migrate gain because employment prospects in their home country have risen relative to neighboring countries.

41. For example, Banki (2004) discusses the implications for host countries (and the degree of integration) of refugees from protracted conflicts, where refugees may stay in host countries for decades.

42. This discussion of the Jordanian experience is based on van Hear (1995). 



\section{Conclusion}

A lthough the data on South-South migration are spotty and much less complete than those for South-North migration, new results from an ongoing effort to build better bilateral migration data suggest that the stock of South-South migrants is large and economically important. The available information (data and literature) indicates that migrants who travel to other developing countries enjoy much lower increases in income, are more likely to be irregular, are subject to greater risks of exploitation, and are more likely to be expelled than are those who migrate from developing countries to industrial countries. Nevertheless, if the benefits from South-South migration are limited, it is also likely that many South-South migrants are poor, or are forced to migrate because of war or ecological disaster. Even small increases in income can have very substantial welfare implications for people in such circumstances.

The magnitude of South-South migration suggests that policymakers need to attend to the issues it raises. Developing-country governments have made efforts to improve the management of South-South migration through bilateral and multilateral treaties, and through participation in multilateral processes. But overall the policy challenges presented by South-South migration remain underappreciated. Remittance fees are particularly high, and bans on remittance transactions funnel remittances into the informal sector. Migration has facilitated the spread of contagious diseases, most spectacularly HIV/AIDS. Tight restrictions on immigration have been associated with substantial increases in irregular migration, which, together with legal migration regimes that give employers control over migrants' freedom, have increased migrants' vulnerability to exploitation and abuse. We have not attempted to formulate concrete recommendations 
on these issues, in part because appropriate policies will depend on local circumstances, and in part because very little information is available on the impact of South-South migration. Even in industrial countries, the welfare analysis of migration is fraught with difficulties owing to uncertainty about distributional implications. In developing countries such analysis is almost altogether absent; it is one of the highest priorities for research in the field of migration. 
Appendixes 



\section{Bilateral Migration Data}

\section{Definition of South and North}

The countries of the "South" are those classified by the World Bank as low- and middleincome countries; the countries of the "North" are the high-income countries. ${ }^{43}$ Other organizations have different ways of classifying countries. The United Nations includes in its South category several high-income countries that do not belong to the Organisation for Economic Co-operation and Development (OECD). Prominent among these are Hong Kong (China), Saudi Arabia, Singapore, and the United Arab Emirates, which are members of the North according to the definition used in this paper, which includes all highincome countries, whether or not they belong to the OECD.

\section{Bilateral Migration Matrix}

The bilateral migration data set of the University of Sussex (as described in Parsons and others 2005) was updated and augmented in order to construct the bilateral migration matrix used in this paper. This bilateral matrix covers 212 countries, of which 154 are lowand middle-income countries, 24 are high-income OECD countries, and 34 are highincome countries that are not members of the OECD. (This data set can be accessed at www.worldbank.org/prospects/migrationandremittances.)

43. See http://www.worldbank.org/data/countryclass/countryclass.html for the World Bank's income-classification criteria. Aykut and Ratha (2004) apply this definition of the South to estimate South-South FDI flows. 
The University of Sussex data set used national censuses, population registers, national statistical bureaus and a number of secondary sources (OECD, ILO, MPI, DFID, UN) to compile bilateral migrant stocks for 162 countries. In an expanded version used for general equilibrium modeling, this database also estimated bilateral information for 64 additional countries for which the censuses had no information on sources of migrants. The authors aimed "to include as many of the world's migrants as possible, to assign them all to specific countries ... and to produce as full and comparable a bilateral database of international migration stocks as is possible under current data dissemination."

While the final filled-in or "composite" matrix of Parsons and others (2005) contains estimates of bilateral migrant stocks for 226 countries, the authors point to the significant heterogeneity in the underlying migration statistics due to a number of factors: disparities across countries in data collection practices, differences in definitions used to classify residents, shifting borders (the breakup of the former Soviet Union, for example, which produced several million new migrants), undercounting of illegal immigrants, under-funded census bureaus, high non-response rates in poor countries, and varying rates of naturalization of the foreign-born - all of which significantly affect comparability of migrant stocks across countries. However, since their aim is to assign every migrant in the world to a specific country, they create several versions of their data set using a series of assumptions. They disaggregate jointly reported countries based on respective population shares (for example, South Asia to Bangladesh, India, Sri Lanka and Pakistan). They estimate bilateral migrant stocks for countries on which there was no information and allocate residual migrants for which the source country was not known using estimated propensities to migrate abroad either globally or to different regions. Finally, they combine the foreign-born and foreign-nationality migrant stock data into a single matrix and scale up their bilateral estimates to the U.N. Population Division's total migrant stocks for each country for 2000. The resulting final bilateral migrant stock matrix is, according to the authors, "the fullest, though arguably the least accurate set of data" among their different versions (Parsons and others 2005). This composite matrix is perhaps most useful for modeling purposes.

We followed the following steps to update and augment the University of Sussex database and construct a bilateral migration matrix:

Information on the countries of origin of migrants in destination countries was drawn from the database of the University of Sussex (Parsons and others 2005). As of August 2006, that data set contained information on source countries of foreignborn migrants for 96 destination countries and source countries of migrants counted by foreign nationality in 105 destination countries.

This information was updated for 30 countries with respect to foreign-born migrants and for 26 countries with respect to migrants' nationality. Out of these, for countries for which there was no existing data, new information was collected for foreign-born migrants in 11 countries and by foreign nationality for 22 countries. Information on bilateral stocks was updated to more recent years for foreign born migrants in 19 countries and by foreign nationality in 4 countries (Table A1).

The data on foreign-born migrants and migrants' nationality were used to create a "combined migrant stock" data set for all 212 countries in our sample. Typically we used information on foreign-born migrants as the default, relying on foreign 
Table A1. DECPG Updates of University of Sussex Data

\begin{tabular}{|c|c|c|c|c|c|}
\hline \multicolumn{3}{|c|}{ Update on migrants' country of birth } & \multicolumn{3}{|c|}{ Update on migrants' nationality } \\
\hline Country & Year & Status & Country & Year & Status \\
\hline Antigua and Barbuda & 2001 & New & Albania & 1989 & New \\
\hline Armenia & 2001 & Updated & Bahamas & 2000 & New \\
\hline Barbados & 1990 & New & Central African Republic & 1988 & New \\
\hline Bolivia & 2002 & Updated & Chad & 1993 & New \\
\hline Brazil & 2000 & Updated & Congo, Rep. & 1984 & New \\
\hline Brunei & 1991 & New & Congo, Dem. Rep. & 1984 & New \\
\hline Cameroon & 1976 & New & Cote d'Ivoire & 1992 & New \\
\hline Cayman Islands & 1989 & New & Gambia & 1983 & New \\
\hline Chile & 2002 & Updated & Guyana & 2002 & New \\
\hline Colombia & 1993 & Updated & Kenya & 1999 & New \\
\hline Ecuador & 2001 & Updated & Liberia & 1974 & New \\
\hline Guatemala & 2002 & Updated & Libya & 1973 & New \\
\hline Honduras & 2001 & Updated & Monaco & 2000 & New \\
\hline India & 2001 & Updated & Mongolia & 2000 & New \\
\hline Madagascar & 1996 & New & Namibia & 1991 & Updated \\
\hline Mexico & 2000 & Updated & Oman & 1993 & New \\
\hline Niger & 1988 & New & Philippines & 2000 & Updated \\
\hline Panama & 2000 & Updated & Russian Federation & 2002 & New \\
\hline Paraguay & 2002 & Updated & Sao Tome and Principe & 1991 & Updated \\
\hline Peru & 1993 & Updated & Senegal & 1976 & New \\
\hline Romania & 2002 & New & Solomon Islands & 1999 & New \\
\hline Russian Federation & 2002 & Updated & Sudan & 1993 & New \\
\hline St. Lucia & 2001 & Updated & Togo & 1981 & New \\
\hline Sao Tome and Principe & 1991 & Updated & Tunisia & 1994 & New \\
\hline Senegal & 1976 & New & Vanuatu & 1999 & Updated \\
\hline Solomon Islands & 1999 & New & Zambia & 2000 & Updated \\
\hline South Africa* & 2001 & New & & & \\
\hline Tanzania & 2002 & New & & & \\
\hline Uruguay & 1996 & Updated & & & \\
\hline Venezuela, Rep. Bov. & 2001 & Updated & & & \\
\hline
\end{tabular}

Source: Individual country censuses. Migrant stocks for South Africa were collected from secondary sources.

nationality data only when data on foreign-born migrants were not available. In some cases, where one or the other type of data seemed incomplete or inconsistent, secondary sources were used. The final data set has information on bilateral migrant stocks for 169 countries (117 countries out of 154 countries in the South and 52 out of 58 countries in the North). 
We had no bilateral migration data for 43 destination countries. The migrants in the 37 South countries were assumed to originate from other developing countries (that is, from the South), whereas migrants in the 6 North countries were assumed to originate from both North and South in the same proportion as migrants whose source countries are known.

Because the latest years for which census data on migrants were available vary across countries, the migrant stocks for each destination country-and breakdown by source country-were scaled to the UN's latest estimates of country-level migrant stocks for 2005 (UN 2005).

The global stock of migrants in our final bilateral matrix of 212 countries was 190.6 million-155.8 million from the South and 34.8 from the North. ${ }^{44}$ These estimates from the bilateral matrix compare favorably with previous estimates of bilateral migration. Harrison, Britton, and Swanson (2004), for example, estimate that migration between OECD countries accounts for 90 percent of total migrants from OECD countries, and that migration between the non-OECD countries in their sample accounts for 70 per cent of the migrants from the non-OECD countries. Our estimates for comparable regions are 85 percent and 59 percent for high-income OECD countries and the rest of the world respectively, with "rest of the world" defined as South and high-income non-OECD countries together.

While we use broadly similar data sources and methods, our database improves upon that of Parsons and others (2005) in several ways. First, in terms of migrant stock data, we have updated the information on bilateral migrant stocks in terms of foreign-born and foreign nationals for 56 countries, using the most recent censuses available and information on bilateral migrant stocks. Because most of the countries for which data was updated are in the South, this exercise considerably improves the coverage of migrants in developing countries. Second, as our objective is to provide a snapshot of migration among developing countries, we rely more on the available census information (supplemented by the UN's latest country-level estimates of migrant stocks for 2005) wherever possible with appropriate caveats, rather than using estimates that rely on country-specific assumptions. For example, the analysis of migration between different South regions includes only "identified" migrants for which both the source and destination country is known. Although this potentially undercounts migration to developing and high-income nonOECD countries-because these have significantly higher number of unidentified migrants relative to high-income OECD countries-it was considered preferable to using assumptions similar to that of Parsons and others (2005) where the nature of bias is unclear. Finally, we allocated unidentified migrants to two broad categories, "Other south" and "Other north," rather than allocating them to specific source countries.

Several caveats should be applied to our estimates. Migrants are defined as either foreign-born or of foreign nationality (where data were not available by country of birth). The two are not conceptually the same. For example, counting migrants by foreign

44. The bilateral matrix with 212 countries excludes the following countries in the U.N. Population Division's 2005 country list: Cook Islands, British Virgin Islands, Western Sahara, Holy See, and Pitcairn. These have a combined migrant stock of 15,709 as of 2005 . 
nationality would exclude the foreign-born who have acquired citizenship in other countries. However, in the absence of complete information for all countries by country of birth, other agencies (OECD, UN) also combine data on country of birth and country of citizenship to arrive at global estimates of migrant stocks.

Interpreting the meaning of migrant stocks also presents some difficulties. Pakistanis in India and Russians in Ukraine became migrants following partition of the original country. Also there are problems in measuring children born abroad to seasonal migrants (for example, Indians in Nepal)—such children appear as foreign born, but they are not necessarily migrants.

All of this indicates that migration data, especially in developing countries but also in the high-income non-OECD countries, is in need of serious overhaul in terms of availability, timeliness, quality, and cross-country comparability. Even the most widely-cited estimates of global migrant stocks available from the United Nations Population Division appear to undercount the actual stock of migrants in a number of countries, because of absence of and reporting lags in census data, and under-reporting of irregular and forced migrants. 



\section{Estimating Bilateral Remittances}

C redible national data on bilateral remittances are not available. Even when such data are reported, they may not be accurate, because funds channeled through international banks may be attributed to a country other than the actual source country. For example, funds flowing from the Gulf region through international banks may be attributed to New York or London (Ratha 2005). Market players and researchers, therefore, have attempted to derive bilateral remittance flows indirectly using bilateral migrant stock data and estimates and assumptions about the remittance behavior of migrants. Harrison, Britton, and Swanson (2005), for example, assume that each migrant sends a fixed average amount.

We have calculated bilateral remittances by allocating remittances received by each developing country among the countries of destination of its migrant nationals. We use three different allocation rules: (i) weights based on migrant stocks abroad; (ii) weights based on migrant incomes, proxied by migrant stocks multiplied by per capita income in the destination countries; and (iii) weights that take into account migrants' incomes abroad as well as source-country incomes (the resulting data sets can be accessed at www.worldbank.org/prospects/migrationandremittances). Each of the three methods is discussed in more detail below.

\section{Using the Share of Migrants in Different Destination Countries as Weights}

The first method of estimating bilateral remittances assumes that remittances $R_{i}$ received by country $i$ are proportional to migrant stocks in the different destination countries. 
Hence, the weight attached to destination country $j$ is

$$
w_{i j}=\frac{M_{i j}}{\sum_{j} M_{i j}}
$$

where $M_{i j}$ is the number of migrants from country $i$ in destination country $j$. Bilateral remittances received by country $i$ from destination country $j$ are therefore $w_{i j} R_{i}$.

A shortcoming of this method is that it assumes that each migrant sends the same amount of remittances regardless of where she lives and no matter what her income in the host country. The large variance of incomes across migrant-receiving countries (and even across countries within each income group) limits the usefulness of this method. This method yields an upper bound estimate of South-South remittances, however, since it attributes the same amount of remittances to a developing country as to a high-income country.

\section{Using Both Migrants Abroad and Income Level in the Host Country}

The second method of estimating bilateral remittances uses migrant stocks in different destination countries and host-country incomes to construct weights. The weight attached to destination country $j$ is:

$$
w_{i j}=\frac{M_{i j} Y_{j}}{\sum_{j} M_{i j} Y_{j}}
$$

where $M_{i j}$ is the number of migrants from country $i$ in destination country $j$ and $Y_{j}$ is the average per capita GNI of migrant-receiving country $j$. Bilateral remittances received by country $i$ from destination country $j$ are therefore $w_{i j} R_{i}$.

Although this method is superior to the first one, as it takes into account both migrant stocks and the average income of the country where the migrant resides, it assumes that each migrant sends a fixed share of her income, regardless of the level of that income or the needs of the family back home. This method yields a lower-bound for South-South remittances.

\section{Using Weights Based on Migrant Stocks, Per Capita Income in the Destination Countries, and Per Capita Income in the Source Countries}

The third method tries to correct for the shortcomings of the first two methods. The average remittance sent by a migrant in destination country $j\left(r_{i j}\right)$ is modeled as a function of the per capita income of the migrant-sending country and the host country.

$$
r_{i j}=f\left(\bar{Y}_{i} Y_{j}\right)= \begin{cases}\bar{Y}_{i} \quad \text { if } \quad Y_{j}<\bar{Y}_{i} \\ \bar{Y}_{i}+\left(Y_{j}-\bar{Y}_{i}\right)^{\beta} & \text { if } \quad Y_{j} \geq \bar{Y}_{i}\end{cases}
$$

where $Y_{j}$ is the average per capita GNI of migrant-receiving country $j, \bar{Y}_{i}$ is the per capita GNI of the migrant's home country, and $\beta$ is a parameter between 0 and 1 . The amount 
sent by an average migrant is assumed to be at least as much as the per capita income of the home country, even when the individual migrates to a lower-income country. The rationale is that the migration occurs in the expectation of earning a higher level of income for the dependent household than what the migrant would earn in her home country. Ideally, the migrants' income should be taken from household survey data; but in the absence of such data, we use per capita GNI in the host country as a proxy for the migrant's income abroad and per capita GNI in the sending country as a proxy for the dependent household's income (assuming that the migrant's remittances compensate at least the counter-factual loss of income due migration).

The level of remittances is assumed to increase with the level of host country income, but at a decreasing rate: $f^{\prime}>0$ and $f^{\prime \prime}<0$. The total amount of remittances received by country $i$ is therefore)

$$
R_{i}=\sum_{j} r_{i j} M_{i j}
$$

The parameter $\beta$ in equation (3) is estimated for each country such that the total of remittances received is equal to $R_{i}$ in equation (4). The parameter $\beta$ is found to be remarkably stable across developing countries ( 0.74 for Bangladesh and China, 0.78 for India, 0.77 for Philippines, and 0.67 for Vietnam). In order to estimate bilateral remittances for all countries, we use the average $\beta$ (equal to 0.75 ) for the top 20 remittance-receiving countries. Equation (3) is then used to create weights so that individual remittances from equations (3) and (4) add up to the total remittances received.

A comparison of these estimates for South-South and North-South remittances calculated using the three different methods is provided in Table 3 in the main text. It is usually impossible to verify the accuracy of these bilateral estimates as most countries in the South as well as in the North do not report sources or destinations of remittance flows. A handful of countries (for example, Bangladesh and the Philippines) do report sources of remittance inflows, but in these data, more flows are likely to be attributed to the United States and Europe where international banks have headquarters (Ratha 2005). Remittances from South countries may also be underestimated due to restrictions on outward remittance flows and irregular status of migrants (for example, Bangladesh does not report any remittance inflows from India even though it has a large migrant population in India). 

APPENDIX C

Remittance Costs 


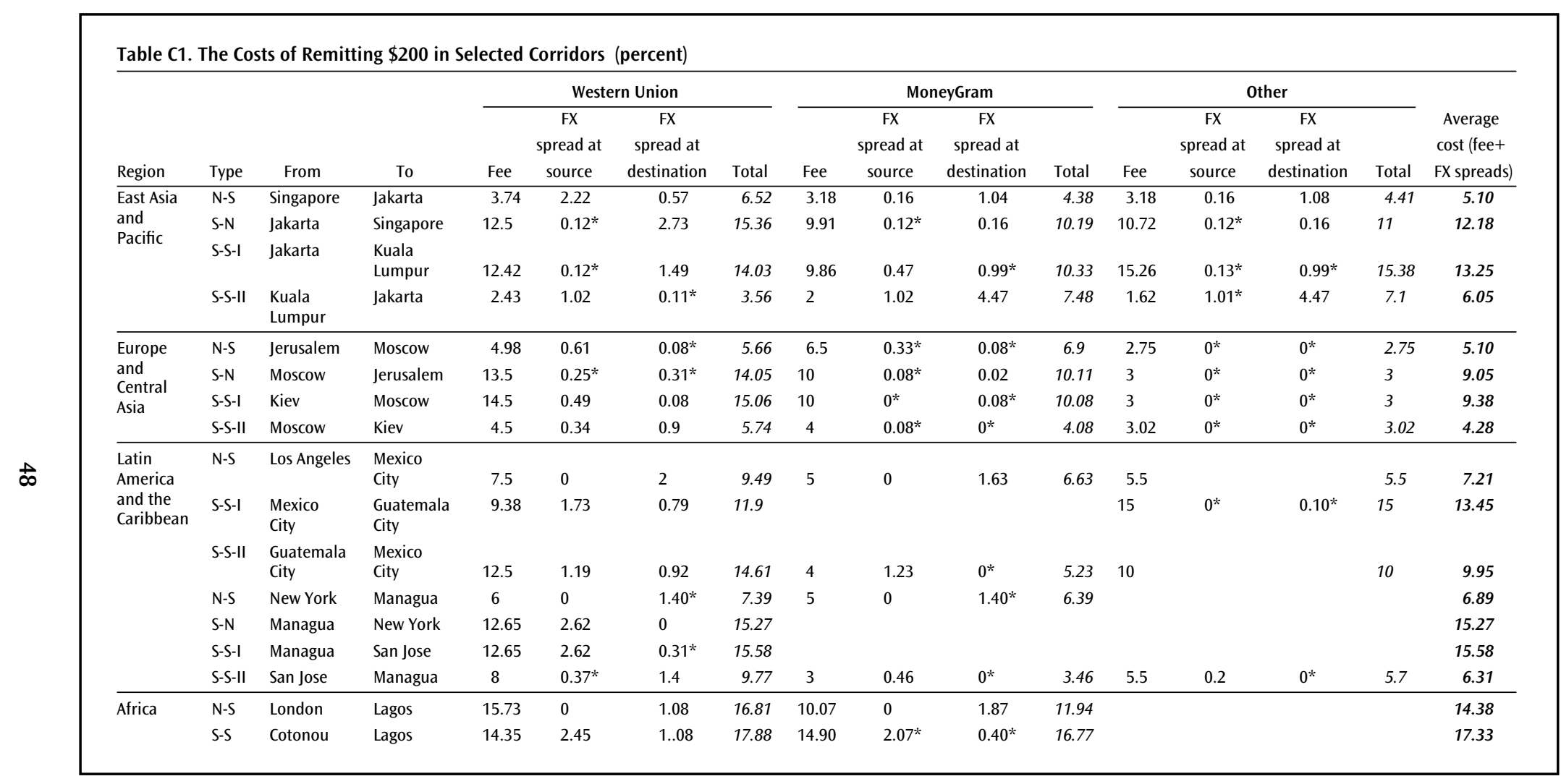

Source: Information collected through phone calls to agents on location (“mystery-shopping”) during August 15-25, 2006, by DECPG staff. Fees include FX commission at source and destination. The following questions were asked: (1) I would like to send $\$ 200$ to my relative in [destination]. How much is the remittance cost? (2) When will the money reach the beneficiary? (3) How many [local currency units] should I bring for $\$ 200$ equivalent? (4) How many [local currency units] will my relative receive? (5) Where is your office or agency located? (6) Can my relative pick up the money from a post office or a bank with whom you may have partnership? (7) Do you provide any other money transfer services (besides Western Union or MoneyGram)?

$\mathrm{FX}=$ foreign exchange.

* FX spread is underestimated. 


\section{References}

Aykut, Dilek, and Dilip Ratha. 2004. "South-South FDI Flows: How Big Are They?" Transnational Corporations 13(1):149-176.

Abella, M. 2005. "Social Issues in the Management of Labour Migration in Asia and the Pacific.” Paper presented at the Regional Seminar on the Social Implications of International Migration, held by ECOSOC/UNPF/IOM and Asian Forum of Parliamentarians on Population and Development, August 24-26, Bangkok.

Adepoju, Aderanti. 2002. "Fostering Free Movement of Persons in West Africa: Achievements, Constraints, and Prospects for Intraregional Migration." International Migration 40(2):4-28.

- 2005. "Review of Research and Data on Human Trafficking in sub-Saharan Africa." International Migration 43(1-2).

Anarfi, John K. 2005. “Reversing the Spread of HIV/AIDS: What Role Has Migration?” In United Nations Population Fund, International Migration and the Millennium Development Goals. New York.

Andrienko, Yuri, and Sergei Guriev. 2005. Understanding Migration in Russia. World Bank Policy Note. Washington, D.C.

Asis, Aruja M. B. 2005a. "Recent Trends in International Migration in Asia and the Pacific." Asia-Pacific Population Journal (December).

_. 2005b. "International Migration and Prospects for Gender Equality." In United Nations Population Fund, International Migration and the Millennium Development Goals. New York.

Athukorala, P. C. 2006. "International Labour Migration in East Asia: Trends, Patterns and Policy Issues.” Asia Pacific School of Economics and Government, Australian National University.

Baldwin-Edwards, Martin. 2006. "Between a Rock and a Hard Place: North Africa as a Region of Emigration, Immigration and Transit Migration." Review of African Political Economy 33(108):311-324.

Banki, Susan. 2004. Refugee Integration in the Intermediate Term: A Study of Nepal, Pakistan, and Kenya. New Issues in Refugee Research Working Paper 108, UNHCR, Geneva.

Bastia, Tanja. 2005. "Child Trafficking or Teenage Migration? Bolivian Migrants in Argentina." International Migration 43(4).

Battistella, Graziano. 2003. "International Migration in Asia.” Migration Patterns and Policies in the Asian and Pacific Region, Asian Population Studies Series 160, United Nations, New York.

Beals, Ralph E., and Carmen F. Menezes. 1970. "Migrant Labour and Agricultural Output in Ghana." Oxford Economic Papers 22(1):109-127.

Blaise, Pierre. 2006. "Taking Stock of Research on Internal Migration in Sub-Saharan Africa." Unpublished paper, World Bank, Washington, D.C. 
Brummer, Daan. 2002. "Labour Migration and HIV/AIDS in Southern Africa." International Organization for Migration Regional Office for Southern Africa.

Castillo, Manuel Angel. 2006. "Mexico: Caught Between the United States and Central America." MIS Selected Readings on Central America, Migration Policy Institute, Washington, DC. http://www.migrationinformation.org/Feature/display.cfm?id=389.

Crush, Jonathan. 2003. “A Bad Labour Policy? Migrant Labour and the New South Africa.” African Studies Center, University of Pennsylvania.

Crush, Jonathan, and Vincent Williams. 2004. "Regionalizing International Migration: Lessons for SADC.” Migration Policy Brief 11, Southern African Migration Project, Queens University, Kingston, Ontario.

Doomernik, Jeroen. 1998. "Labour Immigration and Integration in Low- and MiddleIncome Countries: Towards an Evaluation of the Effectiveness of Migration Policies.” International Migration Papers, International Labour Organization, Geneva.

Fuchs, Deike, and Thomas Straubhaar. 2003. "Economic Integration in the Caribbean: The Development towards a Common Labour Market.” International Migration Papers 61, International Labour Organization, Geneva.

Haque, Md. Shahidul. 2005. "Migration Trends and Patterns in South Asia and Management Approaches and Initiatives." Asia-Pacific Population Journal 20(3).

Harrison, Anne, Tolani Britton, and Annika Swanson. 2004. "Working Abroad: The Benefits Flowing from Nationals Working in Other Economies." Paper prepared for the Meeting of the Technical Subgroup for the Task Force on International Trade in Services, Movement of Natural Persons - Mode 4, Paris, September. Statistics Division, United Nations Department of Economic and Social Affairs.

Harns, Charles. 2006. "Improved Travel Documents in the Context of Overall Migration Management in the Caribbean.” Keynote Address at the Regional Workshop on Travel and Identity Document Security and Issuance Systems, CICTE, Organization of American States, Miami, July 11-13.

Hatton, Timothy, and Jeffrey Williamson. 2002. "What Fundamentals Drive World Migration?” National Bureau of Economic Research Working Paper 9159.

Horakova, Milada. 2000. "Legal and Illegal Labour Migration in the Czech Republic: Background and Current Trends." International Migration Papers 32. International Labour Organization, Geneva.

IOM (International Organization for Migration). 2003. Labour Migration in Asia: Trends, Challenges and Policy Responses in Countries of Origin. Geneva.

- 2004. "Progress in Implementation of the Recommendations of the Colombo Ministerial Meeting." Second Asian Labour Migration Ministerial Consultations, Manila, September 22-24. IOM, Geneva.

- 2005a. Labour Migration in Asia: Protection of Migrant Workers, Support Services and Enhancing Development Benefits. Geneva.

- 2005b. World Migration 2005. Geneva.

. 2005c. "2005c, "Migration Management Assessment: Dominican Republic", report prepared for the government of the Dominican Republic, IOM Washington, DC.

_. 2006. "Migration Management Assessment: Haiti." Report prepared by IOM for the government of Haiti, IOM Washington DC.

IOM and U.S. Department of State. 2005. "A Survey of East Africa Departments of Immigration: Migration Laws, Procedures, Policies and Operations in Kenya, Uganda and 
Tanzania.” Policy review undertaken as part of the Capacity Building in Migration Management program for East Africa, IOM, Nairobi.

Juhasz, Judit. 1999. "Illegal Labour Migration and Employment in Hungary.” International Migration Papers, International Labour Organization, Geneva.

Kanyenze, Godfrey. 2004. “African Migrant Labour Situation in Southern Africa.” Paper presented at the ICFTU-AFRO Conference on Migrant Labour, Nairobi, March $15-17$.

Khadria, Binod. 2005. "Migration in South and South-West Asia." Global Commission on International Migration, Geneva.

Krassinets, Eugene. 1998. "Illegal Migration and Employment in Russia.” International Migration Papers 26. International Labour Organization, Geneva.

Kulis, Marzena, Mukesh Chawla, Adam Kozierkiewicz, and Emilis Subata. 2004. Truck Drivers and Casual Sex: An Inquiry into the Potential Spread of HIV/AIDS in the Baltic Region. World Bank Working Paper No. 37. Washington, D.C.: The World Bank.

Kynoch, Gary and Theresa Ulicki. 2000. "It Is Like the Time of the Lifaqane': The Impact of Stock Theft and Violence in Southern Lesotho." Journal of Contemporary African Studies 18(2).

Lassailly-Jacob, Veronique, Florence Boyer, and Julien Brachet. 2006. "South-South Migration: Example of Sub-Saharan Africa.” European Parliament, Strasbourg.

Lawson, T. 2005. "Sending Countries and the Rights of Women Migrant Workers: The Case of Guatemala." Harvard Human Rights Journal 18 (Spring).

Lee, June. 2005a. "Human Trafficking in East Asia: Current Trends, Data Collection, and Knowledge Gaps.” International Organization for Migration, Geneva.

- 2005b. "A Survey on the Labour Emigration Management Systems of 12 Countries of Origin to the Republic of Korea." IOM, Seoul.

Long, L., S. Le Roux, and R. Wecker. 2006. “'Development-Friendly’ Migration Policies: A Survey of Innovative Practices in Countries of Origin and Destination-The Netherlands and South Africa." Case study prepared for IOM in the context of the IOM/World Bank project on Migration Policies of Relevance to Development under the Knowledge for Change Trust Fund, IOM, Geneva.

Lucas, Robert E. B. 1987. “Emigration to South Africa's Mines.” American Economic Review 77(June):313-330.

- 2005. "Migration and Economic Development in Africa: A Review of the Evidence." Paper prepared for the African Economic Research Consortium Biannual Research Workshop, Nairobi. May 28-June 2.

Lurie, Mark N. 2004. "Migration, Sexuality and the Spread of HIV/AIDS in Rural South Africa." Southern African Migration Project, Queens University, Kingston, Ontario.

Lydie. 2004. Journal of Acquired Immune Deficiency Syndromes 35(1):67-74.

Margolis, Mac. 2006. "Roads to Nowhere; More and more migrants from poor countries are heading to other former backwaters for work." Newsweek International, September 11, 2006.

McKenzie, D. J. 2005. "Paper Walls Are Easier to Tear Down : Passport Costs and Legal Barriers to Emigration.” Policy Research Working Paper Series 3783, The World Bank, Washington, D.C.

MIDSA (Migration Dialogue for Southern Africa). 2004. "Migration and Health.” Summary of remarks from workshop, Cape Town, November 24-26. 
Myers, Norman. 2005. “Environmental Refugees: An Emergent Security Issue.” Paper prepared for the 13th Economic Forum, Prague, May 23-27.

Nangulah, Selma M.W., and Ndeyapo M. Nickanor. 2005. "Northern Gateway: Cross-Border Migration between Namibia and Angola." Migration Policy Papers 38, Southern Africa Migration Project. http://www.queensu.ca/samp/forms/form.html

OECD (Organisation for Economic Co-operation and Development). 2001. "International Migration in Asia: Trends and Policies." Paris.

- 2006. "International Migration Outlook." Paris

Okólski, Marek. 2000. “Illegality of International Population Movements in Poland.” International Migration Special Issue 2000/1.

Parrado, Emilio A., and Marcela Cerrutti. 2003. "Labor Migration between Developing Countries: The Case of Paraguay and Argentina." International Migration Review $37(1)$.

Parsons, Christopher R., Ronald Skeldon, Terrie L. Walmsley, and L. Alan Winters. 2005. "Quantifying the International Bilateral Movements of Migrants." Globalisation and Poverty Working Paper T13, Development Research Centre on Migration, University of Sussex.

Peberdy, S. 1998. “Trading Places: Cross-Border Traders and the South African Informal Sector.” Migration Policy Series 6, Southern African Migration Project, Queens University, Kingston, Ontario.

Pellegrino, Adela. 2000. "Trends in International Migration in Latin America and the Caribbean." UNESCO, Paris.

Petree, J. 2006. "Making the Link Between Migration and Development in Guatemala." Case study prepared for IOM in the context of the IOM/World Bank project on Migration Policies of Relevance to Development under the Knowledge for Change Trust Fund, IOM, Geneva.

Pizarro, Jorge M., and Miguel Villa. 2005. "International Migration in Latin America and the Caribbean: A Summary View of Trends and Patterns.” UN Expert Group Meeting on International Migration and Development, New York, July.

Ratha, Dilip. 2005. "Worker Remittances: An Important and Stable Source of External Development Finance.” In Samuel M. Maimbo and Dilip Ratha (eds), Remittances: Development Impact and Future Prospects. Washington, D.C.: The World Bank.

RCP (Regional Clearing Point). 2003. "First Annual Report on Victims of Trafficking in Southern Eastern Europe.” Belgrade: IOM, Stability pact and ICMC.

Reitzes, Maxine. 2000. "Regionalizing International Migration: Lessons for SADC." Southern African Migration Project, Queens University, Kingston, Ontario.

Rose, Andrew. 2004. “Do We Really Know That the WTO Increases Trade?” American Economic Review 94(1):98-114.

Rybakovsky, Leonid, and Sergey Ryazantsev. 2005. "International Migration in the Russian Federation.” UN Expert Group Meeting on International Migration and Development, New York, July.

Satyanarayana, Adapa. 2001. "Birds of Passage': Migration of South Indian Labour Communities to South-East Asia, 19-20th Centuries A.D.” Working Paper 11, CLARA (Changing Labor Relations in Asia), Amsterdam, http://www.iisg.nl/ clara/clarawp .htm. 
Smith, J. 2006. “Guatemala: Economic Migrants Replace Political Refugees.” Migration Information Source, Migration Policy Institute, Washington, D.C.

Solomon, Hussein. 1996. "Strategic Perspectives on Illegal Immigration into South Africa." African Security Review 5(4).

Theuermann, Gerda. 2005. "Trafficking in Human Beings and the Millennium Development Goal No. 3, Promoting Gender Equality and the Empowerment of Women." In International Migration and the Millennium Development Goals. New York: United Nations Population Fund.

Thiam, Macoumba, Rebecca Pery, and Victor Piche. 2004. "Migration and HIV in Northern Senegal.” Population Reference Bureau. www.prb.org.

United Nations. 2004. World Economic and Social Survey 2004. Department of Economic and Social Affairs. New York.

- 2005. Trends in Total Migrant Stock: The 2005 Revision. Population Division. New York.

- 2006. World Economic and Social Survey 2006. Department of Economic and Social Affairs. New York.

UNAIDS. 2004. Report on the Global AIDS Epidemic: 4th Global Report. Geneva. - 2006. Report on the Global AIDS Epidemic. Geneva.

UNESCAP (United Nations Economic and Social Commission for Asia and the Pacific). 2006. “The Asia-Pacific Migration System.” In International Migration: An Emerging Opportunity for the Socio-Economic Development of the ESCAP Region. Social Policy Paper 6, ST/ESCAP/2165, Bangkok.

United Nations General Assembly. 2006. "International Migration and Development." Report of the Secretary General, May 18, 2006.

UNHCR (United Nations High Commissioner for Refugees). 2006. 2006 Global Refugee Trends. Geneva.

United Nations Population Fund. 2005. International Migration and the Millennium Development Goals. New York.

U.S. Department of State. 2005. "Trafficking in Persons Report.” Washington, D.C.

Van Hear, Nicholas. 1993. "Mass Expulsion of Minorities: An Overview." Journal of Refugee Studies 6(2):275-285.

- 1995. "The Impact of the Involuntary Mass 'Return' to Jordan in the Wake of the Gulf Crisis.” International Migration Review 29(2):352-374.

Vujicic, Marko, Pascal Zurn, Khassoum Diallo, Orvill Adams, and Mario R. Dal Poz. 2004. "The Role of Wages in the Migration of Health Care Prefessionals from Developing Countries." Department of Human Resources for Health, World Health Organization, Geneva.

Weiss-Fagen, P., and M. Bump. 2005. "Remittances from Neighbours: Trends in IntraRegional Remittance Flows.” In S. Wilson (ed.), Beyond Small Change: Making Migrants' Remittances Count. Washington, D.C.: Inter-American Development Bank.

Wickramasekera, Piyasiri. 2002. "Asian Labour Migration: Issues and Challenges in an Era of Globalization.” International Migration Papers 57, International Labour Organization, Geneva.

- 2006. "Labour Migration in Asia: Role of Bilateral Agreements and MOUs." Presentation at the JIPLT workshop on International Migration and Labour Markets in Asia, Tokyo, February 17. ILO, Tokyo. 
World Bank. 1993. Mali: Assessment of Living Conditions. Washington, D.C.

- 1995. Senegal: An Assessment of Living Conditions. Washington, D.C. 2000. Moldova Poverty Assessment. Washington, D.C.

- 2003. Albania Poverty Assessment. Washington, D.C.

- 2005. Global Economic Prospects 2006: Economic Implications of Remittances and Migration. Washington, D.C.

—_ 2006. Costa Rica Poverty Assessment: Recapturing Momentum for Poverty Reduction.Washington, D.C.

Xaba, Jantjie, Pat Horn, and Shirin Motala. 2002. "The Informal Sector in Sub-Saharan Africa.” Employment Sector 2002/10, International Labour Organization, Geneva. 


\section{About the Authors}

Dilip Ratha is a Senior Economist and Manager, Migration and Remittances Team, Development Prospects Group at the World Bank. An expert on remittances and migration, he is the author of the groundbreaking article "Workers' Remittances: An Important and Stable Source of External Development Finance" in Global Development Finance 2003, and a lead author of the World Bank flagship Global Economic Prospects 2006: Economic Implications of Remittances and Migration. He has written extensively on international finance topics including shadow-ratings for unrated countries, future-flow securitization as a tool for development financing, and the rise of South-South foreign direct investment. Prior to joining the World Bank, he worked as a regional economist for Asian emerging markets at Credit Agricole Indosuez, and as an Assistant Professor at Indian Institute of Management, Ahmedabad. He has a Ph.D. in economics from Indian Statistical Institute, New Delhi.

William Shaw became a consultant specializing in international development after retiring from the World Bank in 2003. He worked in the research department of the Bank from 1995-2003, with the bulk of his time devoted to various editions of Global Economic Prospects and Global Development Finance, the Bank's annual publications on current development issues, and to debt sustainability analysis for the Heavily Indebted Poor Countries initiative. From 1988-95 he spent eight years in the Bank's operational departments, serving as the country economist for Tanzania, private sector development specialist for the Caribbean, and country economist for Bolivia. Previously, he worked in the research department on global economic issues. Before joining the Bank, Mr. Shaw worked on the administration of a food assistance program for the U.S. Department of Agriculture.

Since retiring from the Bank Mr. Shaw has pursued consulting work on various issues in development economics, including developing countries and international finance, international public goods, international migration, and corporate restructuring. 


\section{Eco-Audit}

\section{Environmental Benefits Statement}

The World Bank is committed to preserving Endangered Forests and natural resources. We print World Bank Working Papers and Country Studies on 100 percent postconsumer recycled paper, processed chlorine free. The World Bank has formally agreed to follow the recommended standards for paper usage set by Green Press Initiative-a nonprofit program supporting publishers in using fiber that is not sourced from Endangered Forests. For more information, visit www.greenpressinitiative.org.

In 2006, the printing of these books on recycled paper saved the following:

\begin{tabular}{|c|c|c|c|c|}
\hline Trees $^{\star}$ & Solid Waste & Water & Net Greenhouse Gases & Total Energy \\
\hline 203 & 9,544 & 73,944 & 17,498 & 141 mil. \\
\hline $\begin{array}{c}\text { '40' in height and } \\
6-8 \text { ' in diameter }\end{array}$ & Pounds & Gallons & Pounds $\mathrm{Co}_{2}$ Equivalent & BTUs \\
\hline
\end{tabular}



South-South Migration and Remittances is part of the World Bank Working Paper series. These papers are published to communicate the results of the Bank's ongoing research and to stimulate public discussion.

In this paper, we report preliminary results from an ongoing effort to improve data on bilateral migration stocks. We set out some working hypotheses on the determinants and socioeconomic implications of South-South migration. Contrary to popular perception that migration is mostly a South-North phenomenon, South-South migration is large. Available data from national censuses suggest that nearly half of the migrants from developing countries reside in other developing countries. Almost 80 percent of South South migration takes place between countries with contiguous borders. Estimates of South-South remittances range from 9 to 30 percent of developing countries' remittance receipts in 2005. Although the impact of South South migration on the income of migrants and natives is smaller than for South-North migration, small increases in income can have substantial welfare implications for the poor. The costs of South-South remittances are even higher than those of North-South remittances. These findings suggest that policymakers should pay attention to the complex challenges that developing countries face not only as countries of origin, but also as countries of destination.

The data sets on bilateral migration stocks and remittance flows for 212 countries can be downloaded from the World Bank Development Prospects Group website: www. worldbank.org/prospects/migrationandremittances

World Bank Working Papers are available individually or on standing order. Also available online through the World Bank e-Library (www.worldbank.org/elibrary).

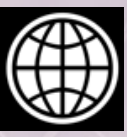

ISBN 0-8213-7072-3

THE WORLD BANK 1818 H Street, NW Washington, DC 20433 USA Telephone: 202 473-1000 Internet: www.worldbank.org E-mail: feedback@worldbank.org

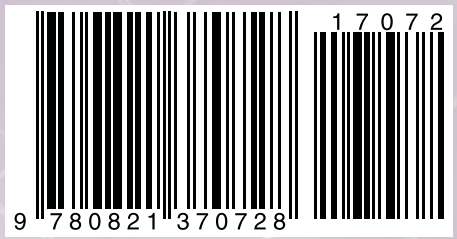

